\title{
บUsisersily
}

\section{Beach morphodynamics and types of foredune erosion generated by storms along the Emilia-Romagna coastline, Italy}

Armaroli, C., Grottoli, E., Harley, M. D., \& Ciavola, P. (2013). Beach morphodynamics and types of foredune erosion generated by storms along the Emilia-Romagna coastline, Italy. Geomorphology, 199, 22-35. [199]. https://doi.org/10.1016/j.geomorph.2013.04.034

Link to publication record in Ulster University Research Portal

\section{Published in:}

Geomorphology

Publication Status:

Published (in print/issue): 01/10/2013

DOI:

10.1016/j.geomorph.2013.04.034

\section{Document Version}

Author Accepted version

\section{General rights}

Copyright for the publications made accessible via Ulster University's Research Portal is retained by the author(s) and / or other copyright owners and it is a condition of accessing these publications that users recognise and abide by the legal requirements associated with these rights.

\section{Take down policy}

The Research Portal is Ulster University's institutional repository that provides access to Ulster's research outputs. Every effort has been made to ensure that content in the Research Portal does not infringe any person's rights, or applicable UK laws. If you discover content in the Research Portal that you believe breaches copyright or violates any law, please contact pure-support@ulster.ac.uk. 


\section{Accepted Manuscript}

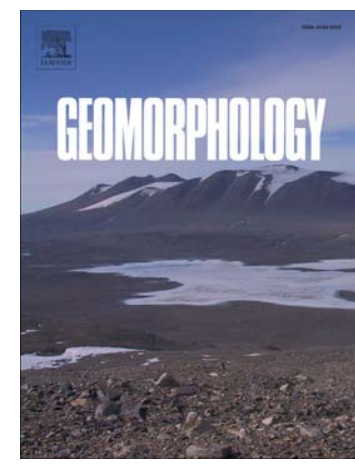

Beach morphodynamics and types of foredune erosion generated by storms along the Emilia-Romagna coastline, Italy

Clara Armaroli, Edoardo Grottoli, Mitchell D. Harley, Paolo Ciavola

PII: $\quad$ S0169-555X(13)00250-X

DOI: doi: $10.1016 /$ j.geomorph.2013.04.034

Reference: $\quad$ GEOMOR 4345

To appear in: $\quad$ Geomorphology

Received date: 22 July 2012

Revised date: $\quad 18$ April 2013

Accepted date: 19 April 2013

Please cite this article as: Armaroli, Clara, Grottoli, Edoardo, Harley, Mitchell D., Ciavola, Paolo, Beach morphodynamics and types of foredune erosion generated by storms along the Emilia-Romagna coastline, Italy, Geomorphology (2013), doi: 10.1016/j.geomorph.2013.04.034

This is a PDF file of an unedited manuscript that has been accepted for publication. As a service to our customers we are providing this early version of the manuscript. The manuscript will undergo copyediting, typesetting, and review of the resulting proof before it is published in its final form. Please note that during the production process errors may be discovered which could affect the content, and all legal disclaimers that apply to the journal pertain. 
Beach morphodynamics and types of foredune erosion generated by storms along the Emilia-

\section{Romagna coastline, Italy}

*Clara Armaroli ${ }^{1}$, Edoardo Grottoli ${ }^{1}$, Mitchell D. Harley ${ }^{1}$, Paolo Ciavola ${ }^{1}$

${ }^{1}$ Dipartimento di Fisica e Scienze della Terra, Università di Ferrara, Via Saragat 1, 44122 Ferrara, Italy, tel: +390532974622 , fax: +390532974767

* Corresponding author: clara.armaroli@unife.it

\section{Abstract}

The objectives of this study are to examine the response of a dune and beach system on the Adriatic coastline in northern Italy to the arrival of storms, compare it with seasonal (months) and mediumterm (3-year) morphodynamic change, and evaluate results predicted by the numerical model XBeach. The studied coastline stretches $4 \mathrm{~km}$ from the Bevano River mouth to the north of the site to the township of Lido di Classe to the south, where the beach is protected by coastal structures. Fieldwork consisted of topographic profile surveys using RTK-DGPS technology (7 times over an approx. 3-year period). 103 samples of surface sediment were collected along 20 of the cross-shore profiles at 6 distinct cross-shore positions, selected on the basis of morphological beach characteristics. Data analyses of dune and beach slopes enabled the study area to be divided into 6 separate morphological zones using the spatial (longshore and cross-shore) variation of morphologies located on the backshore and intertidal beach observed in a preliminary survey of the area. Other criteria were a spatial consistency in beach slopes and/or presence/absence of intertidal morphologies identified in the aerial photographs and Lidar data. The swash zone slope did not show any significant variability for the entire area. A weak seasonal trend in the variability of the 
mean foredune slope was observed, with steeper slopes typically during winter and flatter slopes during summer. Analysis of grain size revealed that the beach sediment is well-sorted fine sand tending to medium, with a decreasing trend in size from the Bevano River mouth southwards towards Lido di Classe. According to the Masselink and Short (1993) classification, the natural part of the study site has an Intermediate Barred Beach (IBB) and following the Short (1999) classification, results in a modally LBT (Longshore Bar-Trough) or LTT (Low Tide Terrace) with a small section being TBR (Transverse Bar and Rip). Storms are considered the main factor controlling changes in the beach and dune slope. The most significant storm was recorded in March 2010 with a peak significant wave height of $3.91 \mathrm{~m}$. Contrary to the seasonal dune trend, several foredune slopes were observed to flatten following this event, which can be attributed to the action of dune slumping from the already weakened dune state. Modelling of foredune erosion, using a process-based model (XBeach), reproduced the erosion of the upper beach and dune toe reasonably well, but is currently limited by the acceptable slope value for dune stability, which does not account for biotic factors (e.g. plant roots). The comparison between the storm impact categories of Sallenger (2000) and the DSF (Dune Stability Factor) of Armaroli et al. (2012) shows a very good correspondence between the effects of the winter 2008-2009 storms and the vulnerability of the dune system predicted using both classifications.

Keywords: dune system, morphological model, XBeach, dune vulnerability.

\section{Introduction}

Dune ridges represent a natural form of coastal protection against the action of waves and storm surges and many numerical models have been developed to predict profile response and sediment exchange between the beach and foredunes (e.g. Vellinga, 1982, 1986; Larson and Kraus, 1989; Kriebel and Dean, 1993). Dunes are also thriving ecosystems which include high diversity plant 
populations ranging from pioneering halophytes to perennial trees like pines. Animal communities are also rich with many invertebrates and vertebrates, including several bird species and mammals. Since the early 1990s, these environments have become the subject of careful management policies, as described for the UK by Doody (1992), and they are also one of the habitats protected by the European Union within its Habitat Directive. Unfortunately in Italy these policies were not established during the economic boom years from the 1960s onwards, where dune ecosystems were of interest as a source of sand for aggregates and as a location for new coastal resorts. At present the Adriatic coastline of Italy has few places where dunes are still present. Notable exceptions include the Po Delta, the Reno River mouth and the area of Lido di Dante-Lido di Classe, south of Ravenna.

The intrinsic feedback mechanism between topography and vegetation is the basis for recent attempts of dune reconstruction in association with beach replenishments. Recent interventions have begun to take place in Italy, with successful campaigns of beach filling in association with fences and re-vegetation (see Nordstrom et al., 2009 for case studies in the Veneto region).

The role of the dunes as protection from flooding, together with the natural value, led researchers to define different methodologies to describe and predict the impact of waves on coastal dunes. One of the main factors causing dune erosion during storms is high water level from storm surges (Edelman, 1968; Hughes, 1981; Stetzel, 1993). This has been observed for the dune response at Lido di Dante - Lido di Classe, where shoreline recession and dune erosion are mostly controlled by surge levels as opposed to wave heights (Armaroli et al., 2012).

Sallenger (2000) developed a four-tier scale of dune impacts that compares the range water levels reach on the beach face with that of the dune foot $\left(D_{\text {low }}\right)$ and dune crest $\left(D_{\text {high }}\right)$. The maximum and minimum water levels $\left(\mathrm{R}_{\text {high }}\right.$ and $\left.\mathrm{R}_{\text {low }}\right)$ used in this scale are defined by:

$$
\mathrm{R}_{\text {high }}=\eta_{\text {mean }}+\mathrm{R}_{2 \%}
$$




$$
\mathrm{R}_{\text {low }}=\mathrm{R}_{\text {high }}-\mathrm{S}_{2 \%}
$$

where $\eta_{\text {mean }}$ is a time-averaged water level that includes tidal and surge effects, $R_{2 \%}$ is the $2 \%$ run-up and set-up exceedence according to Holman (1986) and $S_{2} \%$ is the $2 \%$ exceedence of run-up only, also defined by Holman (1986). Judge et al. (2003) noted that the elevation of the dune crest, $\mathrm{D}_{\text {high }}$, alone is not suitable to evaluate the vulnerability of a dune system because it can be very high above a reference level, but contain a small amount of sand that can be easily eroded by the prolonged attack of waves. Hence, the volume of sand stored in the dune as a sand reservoir is also important when considering dune stability. In FEMA (2003), the area of the "frontal dune reservoir" (defined as the cross-sectional area calculated between the dune foot and dune crest) is used to say if the system is able to withstand a storm. Judge et al. (2003) developed an indicator known as the "crosssection centroid", which along with the dune volume also takes into account the distance between the dune and the shoreline. In the study area, Armaroli et al. (2012) presented morphological thresholds for coastal vulnerability of the dune system. A new indicator was defined, known as the Dune Stability Factor (DSF), that includes the run-up high, as defined by Sallenger (2000), and the cross-sectional area, as defined by FEMA (2003).

A limitation of all state-of-the-art numerical models is a meaningful reproduction of the role of dune vegetation in dissipating the energy of the overtopping sea water and stabilising the dune face. Approaches to modelling the time-dependent evolution of the dune profile during storms can be divided into two approaches (Palmsten and Holman, 2011). The first approach approximates dune slumping by an avalanching algorithm that is triggered when beach and dune slopes exceed certain user-defined thresholds (e.g. Larson and Kraus, 1989; Roelvink et al., 2009). The second approach models dune erosion by assuming that the episodic slumping is proportional to the force of the wave bore striking the dune face (e.g. Overton et al., 1994). The recently-developed hydromorphodynamic model XBeach (Roelvink et al., 2009) makes advances into time-dependent dune erosion modelling by taking into account infragravity waves that are the main cause of wave 
collisions with the dune face during storms (Raubenheimer and Guza, 1996). It has been designed based on the four categories of storm impacts of Sallenger (2000) and has been shown to successfully reproduce the post-storm morphology because of frontal dune erosion and overwash processes at several different sites worldwide, including the USA (Roelvink et al., 2009; McCall et al., 2010; Lindemer et al., 2010), Portugal (Vousdoukas et al., 2012) and Australia (Splinter and Palmsten, 2012). The avalanching algorithm used by XBeach limits "wet" model grid cells (i.e. areas submerged by water) to smaller slopes than for "dry" cells. This means that as waves collide with the dune face, the transition at the dune foot from dry to wet sets off a chain reaction in the model that causes the dune to slump (Roelvink et al., 2009). The default values for these slope limits, however, are based on typical post-storm dune slopes observed in the field and may not be applicable to vegetated dune systems.

The aim of the current paper was to understand the physical mechanisms that control the response of the dune and beach system at short (storm) and medium-term (months to year) time-scales. The effects of storms on the dune system were investigated by comparing pre- and post-storm surveys with the results of the numerical hydro-morphological model XBeach. Two dune impact indicators were used to describe the vulnerability of the system: the impact scale of Sallenger (2000) and the Dune Stability Factor (DSF) of Armaroli et al. (2012). The beaches were additionally classified using the most widely known morphodynamic conceptual models.

The paper provides a new comparative test between two different approaches for the development of storm impact indicators, integrating them with state-of-the-art numerical modelling. The study site is located in the northern Adriatic coast of Emilia-Romagna, which includes one of the best preserved dune systems at a regional level. The current paper also provides one of the few examples of the application of standard morphodynamic classifications to northern Adriatic beaches.

\section{Study Area}


The Lido di Classe-Bevano area is a $4 \mathrm{~km}$ stretch of sandy beaches along the Emilia-Romagna coastline in northern Italy and faces the Adriatic Sea (Fig. 1). The site is a mixture of urbanised and relatively pristine coastal environments. The seaside town of Lido di Classe is located at the southern boundary of the site. Offshore from the town is a series of shore-parallel emerged and submerged breakwaters that offer some protection during energetic wave conditions. North of the town is a natural park consisting of vegetated dunes and no coastal protection. A river mouth (Torrente Bevano) is located at the northern edge of the study site inside the natural park.

The wave climate of this region has generally small waves, with $91 \%$ of significant wave heights below $1.25 \mathrm{~m}$. The prevalent wave direction is from the east, whereas the most intense storms are from the ENE (known as the "Bora wind"). The Bora is a strong, cold, gusty wind that blows intermittently but mainly during the winter. It has a strong influence on the wave climate of this region and the general circulation patterns of the entire Adriatic Sea. South-easterly waves are much less significant, because they are sheltered to some degree by the Conero Headland approximately $120 \mathrm{~km}$ south of the site. The area is microtidal with a mean neap tidal range of $30-40 \mathrm{~cm}$ and a mean spring tidal range of $80-90 \mathrm{~cm}$. The tidal signal has diurnal and semidiurnal components. Despite the small tidal range, the impact of high water levels on beach morphological changes and dune erosion can be important (Armaroli et al., 2012) because of storm surge. Even low return period events (e.g. a 1-in-10 year event) can reach elevations exceeding $1 \mathrm{~m}$ above MSL (Masina and Ciavola, 2011). This is particularly the case during SE wind conditions, where the fetch across the Adriatic Sea is greatest and swells occur with a low-pressure weather system located over northeast Italy.

Many detailed studies have been published by previous authors for the Bevano river mouth and the coastline immediately to the north (Armaroli et al., 2005; Balouin et al., 2006; Armaroli et al., 
2007a; Sedrati et al., 2008, 2009; Armaroli and Ciavola, 2011). To the south of the river mouth, the only published works are those of Armaroli et al. (2007b) and Grottoli and Ciavola (2012). According to Armaroli et al. (2007b), the closure depth of the submerged beach is between 6 and 7 $\mathrm{m}$, confirmed by a dominant mud fraction at a depth of $6 \mathrm{~m}$.

The study area comprises the natural park between the Bevano mouth and the groins of the northern edge of Lido di Classe (Fig. 1) and the constructed part characterised by a high building density and artificial protection structures, such as groins, breakwaters and dikes. A well-developed dune system is present along this area, with foredunes up to $3 \mathrm{~m}$ high. The landward part of the dune system is backed by stabilized dunes which pass inland into a dense pine forest. Starting at the south of the study area, the beach in front of the Lido di Classe village is wide (60-100 m), with a gentle slope of around 0.02 . It is characterised by the presence of tombolos that form between the beach and the breakwaters. Moving northwards the beach narrows in the area protected by groins. A gently-sloping and wide terrace is present in the intertidal and subtidal areas, with its seaward edge located at 60-100 $\mathrm{m}$ from the shoreline in water depths between $0.5 \mathrm{~m}$ and $1 \mathrm{~m}$ MSL (Calabrese and Lorito, 2009). In the natural area, the intertidal and shallow subtidal beach becomes more irregular with troughs, ridge and runnels, swash bars. The submerged beach is characterised by a linear bar, with a crest that stays between 100 and $300 \mathrm{~m}$ from the shoreline and at a depth varying between $1.5 \mathrm{~m}$ and $3 \mathrm{~m}$ below MSL (Calabrese and Lorito, 2009).

Figure 1 goes approximately here

\section{Methods}


The study area is subdivided into six zones to schematise and facilitate the analysis of the survey data, the description of the morphological variations, the location and distribution of the sediment and the definition of the morphodynamic classification. The subdivisions were based on different criteria among which the most important is the spatial (longshore and cross-shore) variation of morphology of the backshore and intertidal beach as observed by a preliminary survey of the area and by photographic archives collected during the surveys. Other criteria were a spatial consistency in beach slopes and presence or absence of intertidal morphologies identified in the aerial photographs and Lidar data. The topographic Lidar survey of the whole area, performed on 10 March 2009, produced a Digital Surface Model (DSM) with a cell size of 1x1 m. Digital aerial photographs were captured over the area at the same time with an image resolution of 39 Mpixels. Topographic surveys were undertaken in September 2008, February 2009, September 2009, February 2010, March 2010, October 2010 and March 2011. All the surveys were performed by wading using RTK-DGPS survey technology. The chosen reference level for the surveys was the mean sea level measured in Genova (the $0.0 \mathrm{~m}$ reference level for Italy, hereafter referred to as MSL) and the measurements were done along cross-shore profiles spaced at equal distances (100 $\mathrm{m})$. The profiles have been measured from the rear crest of the dunes down to a depth of $1 \mathrm{~m}$ to 1.5 m below MSL.

The seven surveys were carried out after major storms (Fig. 2) to identify the effect of the storm waves on the dune system and on beach erosion/accretion. Five surveys were done after storms that were close to the 1 year return period $\left(H_{s}=3.3 \mathrm{~m} ; T_{s}=7.7 \mathrm{~s}\right.$, Idroser 1996), while two surveys were carried out after storms that were close to the 5 year return period (Harley et al., 2011).

Two bathymetric surveys were performed in September 2008 and September 2009 using a single beam Odom echosounder (vertical accuracy $=1 \mathrm{~cm}$ ) with a positional accuracy of less than $1 \mathrm{~m}$ 
(Omnistar DGPS correction) along equally spaced profiles (100 m) corresponding approximately to the topographic profiles. The bathymetric profiles were on average extended offshore for more than $200 \mathrm{~m}$ and reached a water depth of almost $4 \mathrm{~m}$. The reference level was mean sea level, with tidal corrections of the soundings performed using the tide gauge of Porto Corsini, just $10 \mathrm{~km}$ north of the site.

During the summer, beach topography was not surveyed because no significant morphological changes occurred because of mild weather conditions, and the beach was covered with umbrellas and chairs and too many beach users. Also, it is common practice to artificially flatten the beach in spring and summer where tourist facilities are located, and a survey would not reveal configurations generated by natural processes.

Figure 2 goes approximately here

Figure 3 illustrates the scheme used to subdivide each profile into three cross-shore segments, which were then used to evaluate slope variations in each part. The three portions are between: 1) the dune crest and dune foot (dune front); 2) the dune foot and berm crest (backshore) and 3) the berm crest and trough (swash zone). The slope of the three segments was calculated for every survey date and for each of the 40 profiles along the study area.

Figure 3 goes approximately here

\subsection{Beach and dune sediment sampling}


To provide grain size information on the studied beaches, sediment sampling took place in October 2010 along the profiles used for monitoring morphological change (Fig. 1). Sampling occurred along 20 profiles, corresponding to even-numbered lines. Cross-shore sampling positions were chosen using the morphological criteria in Fig. 3. Ideally, six samples would have been obtained for each profile, but samples were less on some occasions, e.g. where the inner bar/low tide terrace was absent. In total 103 samples were collected.

\subsection{Grain size analysis and estimation of sand settling velocity}

Particle size analysis was undertaken after drying the samples at $105^{\circ} \mathrm{C}$. A set of 12 standard ASTM sieves was used with intervals of $1 / 2 \varphi$, covering a range between- $1 \varphi$ and $4 \varphi$. Grain size parameters (Folk and Ward, 1957) were calculated using the Gradistat program (Blott and Pye, 2001). Further analyses of sediment composition were done on samples collected at the berm (position 3 in Fig. 3) on every fourth survey profile (e.g. MS4, MS8,..,MS36, MS40, see Fig. 1). The Calcium Carbonate content was estimated using a standard electronic gas-volume analyzer following reaction with $\mathrm{HCl}$. The sediment density of these samples was estimated with a standard liquid pycnometer. The Dean (1973) parameter, aka the non-dimensional settling velocity, was calculated using the Le Roux (1996) formula. The Dean parameter was then used for all the morphodynamic classifications.

\subsection{Morphodynamic classification}

The study site was classified according to the morphodynamic classes of Masselink and Short (1993), using the dimensionless sediment fall velocity $(\Omega)$ and the ratio between the Mean Spring Tide Range (MSR) and the breaking wave height $\left(\mathrm{H}_{\mathrm{b}}\right)$, known as the Relative Tidal Range (RTR, Masselink and Short 1993; Masselink and Hegge, 1995). The RTR for the area just north of the study site was previously calculated as 1.66 by Armaroli and Ciavola (2011). Our study site has the 
same meteorological and hydrodynamic conditions, so the same RTR value was adopted. A second classification of the beaches was done following the scheme of Short (1999), based only on $\Omega$.

Six profiles were chosen as representative of the whole study area and of each alongshore zone: MS2 for zone 1, MS9 for zone 2, MS17 for zone 3, MS24 for zone 4, MS32 for zone 5, MS39 for zone 6 (Fig. 1). The profiles were chosen because they incorporate all the main morphodynamic characteristics of each of the six zones, including beach and dune response to storms.

\subsection{Modelling of beach and dune profile response to storms}

The XBeach model solves coupled 2DH equations for wave propagation, flow, sediment transport and bottom changes, for varying (spectral) wave and flow boundary conditions (Roelvink et al. 2009). It resolves the wave-group and infragravity time scales, which are responsible for most of the swash and overwash processes, which thus can be modelled explicitly. The code is well suited for studying dune erosion, overwash and breaching as it can represent complex geometries and contains essential physics related to the swash motions during storms.

Two significant storms that occurred over the monitoring period (Fig. 4) were selected for XBeach modelling. Wave data were derived from the Cesenatico wave buoy located approximately $20 \mathrm{~km}$ south of the site in $10 \mathrm{~m}$ water depth. Tide data were obtained from the same Porto Corsini tide gauge used to correct the echo sounder readings. The first storm occurred between 1-3 December 2008 and was characterised by small waves (peak $\mathrm{H}_{\mathrm{s}}=1.47 \mathrm{~m}$ ) but very high water levels (peak $\mathrm{h}=$ $0.92 \mathrm{~m}$ ). The direction of this storm was from the east (direction of maximum wave energy of $91^{\circ}$ N) with wave periods around 8 seconds and a maximum peak wave period $\left(\mathrm{T}_{\mathrm{p}}\right)$ of $9.1 \mathrm{~s}$. The second storm occurred between 9-10 March 2010 and represented a combination of very large waves (peak $\mathrm{H}_{\mathrm{s}}=3.91 \mathrm{~m}$, roughly equivalent to a 5 year return interval) and high water levels (peak $\mathrm{h}=0.93 \mathrm{~m}$ ). 
The direction of this storm was from the ENE $\left(59^{\circ} \mathrm{N}\right)$, with slightly longer wave periods around 9 $\mathrm{s}$, with maximum $\mathrm{T}_{\mathrm{p}}$ of $10 \mathrm{~s}$.

Figure 4 goes approximately here

One-dimensional XBeach modelling for these two storms was undertaken at two profile lines (Profiles MS17 and MS22) within the natural section. XBeach modelling within the protected area was not undertaken because this requires more-complex two-dimensional modelling to accurately represent the hydrodynamics adjacent to offshore breakwaters (Harley et al., 2011). A combination of the morphological data was used to create complete cross-shore profile lines for input into the model at these two locations. For the 1-3 December 2008 storm, pre-storm morphology was obtained from the topographic and bathymetric survey conducted between 29 September and 1 October 2008. Topographic, but not bathymetric, measurements conducted between 9-12 February 2009 were used for the post-storm measurements. For the March 2010 storm, pre-storm morphology was derived from the topographic survey undertaken in February 2010 and the bathymetric survey undertaken in September 2009. Topographic, but not bathymetric, measurements were performed one week after this storm (between 16-19 March) and used for the post-storm measurements. Statistics of the initial profile configurations and the measured beach response after the storms (shoreline retreat and volume lost above MSL) are listed in Table 1. These statistics reveal a loss of sand volume up to a maximum of $13.2 \mathrm{~m}^{3} / \mathrm{m}$ above MSL and shoreline retreat of $8.7 \mathrm{~m}$.

The XBeach model is still in its development phase and requires further testing of the input parameters (Vousdoukas et al., 2012). Fourteen combinations of XBeach parameter settings were tested in this study for each profile and storm. These combinations were obtained by increasing and decreasing certain individual parameters from two different parameter sets - the XBeach default 
settings and a second experimental parameter set (hereafter called Parameter Set 1) suggested by model developers. The individual input parameters modified were those deemed most critical to dune erosion: the critical avalanching slope for dry cells ('dryslp'), the critical avalanching slope below water ('wetslp') and the maximum allowed wave height over water depth in shallow water ('gammax'). Wet cells and dry cells are defined in the model by a threshold depth 'eps', which has a default value of $0.005 \mathrm{~m}$ and a value of $0.01 \mathrm{~m}$ for Parameter Set 1 . For further details of the parametric model set-up, see Harley et al. (2011).

Performance of the model was assessed in terms of the Brier Skill Score (BSS), which relates the variance of the difference between measured and modelled values to the variance of measured values (Roelvink et al., 2009). A BSS of 1 represents perfect model performance, whereas 0 implies no model skill and a negative value meaning the model is worse than a no-change prediction. The model performance of the backshore is of interest to this study, so BSS values only above MSL were also calculated.

\subsection{Dune vulnerability}

To describe dune vulnerability, two storm impact indicators were calculated and compared to the pre- and post-storm topographic profiles (between September 2008 and February 2009). The first indicator is the Dune Stability Factor (DSF) of Armaroli et al. (2012) and the second is the impact scale of Sallenger (2000). The comparison was based on the same profiles used in the XBeach simulations. Impact indicators were calculated using only storms that occurred during the 20082009 winter (1-3, 12 and 25 December 2008). This choice was done because the inland extension of the profiles to evaluate the DSF must include the whole dune topography (from the back-dune to the dune foot), and the sections that satisfy this condition are those surveyed in September 2008 and February 2009. The DSF is calculated as the ratio between the cross-sectional area of the first line 
of dunes (defined as the "first line of defences" in Armaroli et al., 2012), computed between the dune foot and the dune crest, and the cross-sectional area computed between the maximum water level (storm surge + wave set-up + wave run-up), reached during a storm, and the dune crest. Thus, all the dune area activated by the storm waves is included in the computation. The first storm (1-3 December 2008) was used in the XBeach modelling and its characteristics are presented in Fig. 4. The 12 December 2008 storm was characterised by high waves and surge levels (peak $\mathrm{H}_{\mathrm{s}}=2.17 \mathrm{~m}$; peak $\mathrm{h}=0.87 \mathrm{~m}$ above MSL, Fig. 2) and the 25 December 2008 storm by high waves (peak $\mathrm{H}_{\mathrm{s}}=$ $3.18 \mathrm{~m}$, close to the 1 year return period, Fig. 2) and a relative low surge elevation $(\mathrm{h}=0.55 \mathrm{~m}$ above MSL, close to the level reached by the Spring High Tide).

\section{Results}

\subsection{Morphological variability of the beach-dune profile}

The overall evolution of six profiles is presented in Figure 5, with the baseline survey performed in September 2008 represented by the black line. Comparison of the profiles reveals that Zone 1 shows a progressive flattening of the beach. The dune in Zone 2 remains almost unchanged and the backshore remains stable. Zone 3 experiences retreat of the dune foot while the dune height remains stable. Zone 4 suffers from the negative impact of the storms (comparing the baseline survey and March 2011 topographies). Zones 5 and 6 are located behind the breakwaters and, thus, show little variability. Zone 6 does not include the dune because it is in the urbanized area of Lido di Classe and, if dunes are present, they are behind or among buildings and do not represent typical morphological conditions. The highest values of the dune crest are reached in Zones 2 and 5 (Fig. 5), with crest heights of $3 \mathrm{~m}$. In these zones, the dune reaches the largest width (a maximum of 35$40 \mathrm{~m}$ in zone 2) while the lowest values are in Zone 3 and 4 (a minimum of $15 \mathrm{~m}$ in Zone 4) which are the zones experiencing most erosion. 
Figure 5 goes approximately here

Slope variations of every cross-shore beach segment (swash zone, backshore, dune front; Figure 3) in each alongshore zone are relevant to understanding the overall evolution of the beach/dune and its vulnerability to storms.

The average values of the three slope segments were computed for all profiles included in each zone and for every survey (Fig. 6). Results are presented below for the dune front, the backshore and the swash zone. Zone 6 was excluded from the analysis of the variation of dune front slope (Fig. 6, lower panel) because the dunes are among buildings.

Figure 6 goes approximately here

From Figure 6 it is clear that the steepest frontal dune slopes are in Zones 3 and 4 (highest slope values in Zones 3 and 4 of 1.02 and 1.91, respectively). The frontal dune slope is at its flattest in the boundary Zones 1 and 6 , where the minimum value is 0.08 and the maximum 0.12 . Intermediate values are found in Zones 2 and 5. The highest slopes in Zones 3 and 4 are caused by the proximity of the dune to the sea (i.e. narrow beach), which maintains a steep profile through the continuous removal of sediment by wave action at the highest tides. This indicates a higher impact of storms in these areas. The almost vertical slope of the frontal dune face in these two areas results from the presence of vegetation that is able to keep the sediment in place through the cohesive effect of the roots and organic matter. Without the plants, the slope would collapse and reach an equilibrium slope of the grain size typical of the area. 
In Zones 1, 2, 3 and 4, a decrease of dune slopes is evident over the summer (i.e. FebruarySeptember 2009; March-October 2010). An increase of the slopes occurred during the winter (i.e. September 2008-February 2009, September 2009-February 2010, October 2010-March 2011).

In Zone 3 the slope of the dune had almost constantly been increasing during the three years of monitoring. The only two exceptions are represented by the decrease between February and September 2009 and between March and October 2010. Zone 4 shows again an overall increase but two major exceptions arise: one between February and March 2010 and the other between March and October 2010. The March 2010 storm provided the opportunity to survey the impact of of a large event on the beach and dune systems. Slope values for this period show an increase in Zones 1, 2, 3 and 5 while in zone 4 a consistent decrease occurs.

The average higher value of the backshore was 0.10 and was measured on 3 February 2009 in Zone 3. The beach in the boundary zones (1 and 6) is almost flat (0.01-0.03). At the northern end, near the Bevano mouth, the beach is also controlled by river processes, with occasional floods that tend to flatten the beach. Unpublished observation by the authors also document the formation of big overwash fans with a wide and flat beach profile after the exceptional surge that occurred on 1 December 2008, when Sedrati et al. (2011) identified overwash development north of the mouth. At the other side of the study area, the beach is located behind the breakwaters where tombolos occur and where the wave energy is dissipated by the offshore structures.

In Fig. 6 variability of the beach slope is small on the backshore and the swash zone. Slope values range from gently-sloping (0.01), typical of a dissipative beach, to 0.13 in Zones 3 and 4, meaning that the beach can become steep and reflective). These last two zones are the most variable, ranging from $0.04-0.05$ up to $0.07-0.13$. Zones 1 and 6 are very mild even if the maximum values in the 
swash can reach $0.06-0.07$, meaning that the berm that forms in winter can also generate steep slopes inside the protected area.

The intertidal zone has, as expected, large variability in slope values. The only evident result for this segment of the profile is the constant lowering of the intertidal zone steepness in Zone 6 (not represented here), which can be attributed to the presence of the structures. Thus, variation and evolution of the slope of the intertidal segment will focus on the variation of the slope of the backshore and, more importantly, of the frontal dune.

\subsection{Sediment characteristics of the beach-dune systems}

The results from the analyses of particle sizes show that the whole study area is composed of fine sand (mean grain size ranges between $0.179 \mathrm{~mm}$, Zone 6 , and $0.243 \mathrm{~mm}$, Zone 1). The amount of $\mathrm{C}_{\mathrm{a}} \mathrm{CO}_{3}$ ranges between $23 \%$ for Zone 5 and $28 \%$ for Zone 2 and 3 . Note that the results were obtained after averaging single analyses output across all samples for each alongshore morphological zone. The dominant sediment class is a well-sorted fine sand, with size decreasing progressively from the Bevano mouth (Zone 1) southwards, with the finest beaches located behind the structures of Lido di Classe (Zone 6).

The presence of considerable calcium carbonate in the sediments introduces a slight deviation in the overall sample density which reaches 2.71 . The provenance basin of the sediments (northern Apennines) does not include carbonate rocks, so this fraction is related to the presence of a bioclastic component in the sediment (e.g. shell fragments), as confirmed by visual inspection of the samples under an optic microscope.

\subsection{Morphodynamic classification}


The extended topographic and bathymetric profiles, for the September 2009 survey, of the six representative profiles can be found in Figure 5. The represented profiles extend from the dune crest down to an approximate depth of $3.5 \mathrm{~m}$. A comparison between the beach state predicted by the morphodynamic classifications and the morphologies (Fig. 7) is presented.

Figure 7 goes approximately here

The six zones are classified as follows:

- Zone 1 ( $\Omega=3.66)$ : Intermediate Barred Beach according to Masselink and Short (1993) and Longshore Bar-Trough / Low Tide Terrace, LBT / LTT, according to Short (1999), Figure 7. This area is characterised by the presence of an intertidal bar that is sometimes attached to the shore (see the low tide terrace in the profiles of Fig. 5). In Figure 7 a submerged linear bar is visible at $130 \mathrm{~m}$ from the shoreline and a depth between $1.5 \mathrm{~m}$ and $2.0 \mathrm{~m}$ below MSL. In Zone 1 the bar is symmetric with a pronounced (pointed) crest.

- Zone $2(\Omega=4.09)$ : Intermediate Barred Beach according to Masselink and Short (1993) and LBT / LTT according to Short (1999), Fig. 7. This zone is characterised by the presence of a linear submerged bar and an intertidal area with a low tide terrace. The submerged bar is almost $100 \mathrm{~m}$ from the shoreline at a depth between $1.5 \mathrm{~m}$ and $2.0 \mathrm{~m}$ below MSL. The shape of the crest of the outer bar is almost symmetric.

- Zone 3 ( $\Omega=3.90)$ : Intermediate Barred Beach according to Masselink and Short (1993) and LBT / LTT according to Short (1999), Fig. 7. The morphological characteristics are the same as Zone 1 and 2. The outer bar crest is asymmetric.

- Zone 4 ( $\Omega=4.69)$ : Intermediate Barred Beach according to Masselink and Short (1993) and Longshore Bar-Trough / Transverse Bar and Rip (LBT / TBR) according to Short (1999), 
Fig. 7. The inner bar is attached to the shore through two oblique bars while the outer bar is about $130 \mathrm{~m}$ from the shoreline at a depth of $1.5 \mathrm{~m}$ and $2.0 \mathrm{~m}$ below MSL. The outer bar is linear, but a rhythmic form is present where the northward oblique bar attaches to the inner bar. According to Short (1999), the spacing between the transverse bar for oceanic coasts should be between $150 \mathrm{~m}$ and $200 \mathrm{~m}$. In this area the spacing between the transverse bars is similar to the one described in the literature. The shape of the crest of the outer bar is still asymmetric.

- Zone $5(\Omega=5.07)$ : Dissipative Barred Beach according to Masselink and Short (1993) and LBT / LTT according to Short (1999), Fig. 7. Bar morphologies are present even if the structures strongly influence the shape of the backshore and submerged beach. One submerged linear bar is located almost $65 \mathrm{~m}$ from the shoreline. The crest of this submerged bar is very asymmetric. Offshore of the bar a sand deposit because of the presence of the submerged breakwater is visible. The intertidal area is characterised by a low terrace that forms between the groins.

- Zone $6(\Omega=5.61)$ : this zone was not classified according to Masselink and Short (1993) and Short (1999) because it is protected by emerged breakwaters and the morphologies (e.g. tombolos) are generated by the structures and the interaction with currents, waves and sediment transport.

\subsection{Modelling of profile change under storm forcing}

The Brier Skill Score values for the 56 model runs of the two storms at Profiles MS17 and MS22 are listed in Table 2. Considering all fourteen different combinations tested, the optimal settings for the BSS over the 1-3 December 2008 and the 8-10 March 2010 storms was found using Parameter Set 1 and increasing the wetslp parameter in XBeach to 0.5 (from a default value of 0.3 ). The 
average BSS across the two profile lines is 0.38 and 0.14 for the December 2008 and March 2010 events, respectively. Plotting the model results for these optimal settings (Fig. 8) reveals that the model replicates frontal dune erosion with reasonable accuracy. Leaving the "wetslp" at its default value and using Parameter Set 1 results in slightly improved performance for the December 2008 storm (average BSS for the two profiles $=0.44$ ) but a significant overestimation of frontal dune erosion for the more energetic March 2010 event (average BSS = -1.92). When the "wetslp" parameter is reduced to a value of 0.1 , an overestimation of frontal dune erosion by the model occurs for both storms and the dune is completely destroyed for the March 2010 simulation at profile MS22.

The model (using the optimized settings) performs less consistently in the backshore and swash zones, with an overestimation of erosion for the December 2008 storm at profile MS17 and an underestimation for the March 2010 storm at MS22. A similar observation was found by Vousdoukas et al. (2012), who suggested that using an alternative sediment transport equation based on the equilibrium sediment concentration formulation of Van Thiel de Vries (2010) might provide improved model results. XBeach also imposes many different user-defined limiters on sediment transport processes in very shallow water to prevent unrealistic sediment concentrations and flow velocities. Whereas one of these limiters ("gammax") was tested in this study, it is possible that further calibration of other limiters could improve model performance in this zone.

Another factor that can affect the results of model calibration is that pre-storm profile lines were measured several weeks prior to the storm in the case of topographic data and several months prior in the case of bathymetric data. Splinter and Palmsten (2012) assessed the effects of different bathymetries on XBeach model results and found that dune erosion decreased for more LTT type bathymetries and increased for more energetic bathymetries with offshore sandbars. Nevertheless the model results were found to be less sensitive to the input bathymetry than to the input parameters for the hydrodynamic and morphodynamic processes. This highlights the importance of 
gaining a thorough understanding of how the model performs under various parameter combinations and for different environmental settings.

Figure 8 goes approximately here

\subsection{Results of dune vulnerability}

The results of the impact scale of Sallenger (2000) and the DSF of Armaroli et al. (2012) were compared to XBeach results and to the observed impacts for the 1-3 December 2008 event (Fig. 8) at the same two profile lines (i.e. MS17 and MS22). The ratio between $\mathrm{R}_{\text {high }}$ and $\mathrm{D}_{\text {high }}$ described in Sallenger (2000) is always below 1 for both profiles and for all storms, thus indicating a "collision regime" (erosion of the foredune). The DSF values meanwhile are between $30.8 \%$ and $64.2 \%$. The range between $20 \%$ and $75 \%$ indicates "frontal dune erosion". The results are in agreement with XBeach model runs and with the observed impacts.

\section{Discussion}

\subsection{Seasonal profile variability, storm response}

No relationship between beach and dune morphodynamics was found by comparing beach slopes and foredune slopes from successive surveys. The only qualitative relationship found was some correspondence between beach width and the frequency of dune cliff formation, as proposed by Ollerhead et al. (2013). Saye et al. (2005), after examining Lidar dune surveys around the UK coastline, concluded that a universal association between beach and dune erosion/accretion cannot 
be found. A locally defined threshold of beach width can be considered but it is more appropriately done at a single profile location and not at the scale of the whole study site.

The backshore, in general, does not follow the seasonal trend in slope values observed by other authors (e.g. McLean and Shen, 2006), although the highest slope values occur during the winter, when the erosive effect of the waves is more significant (Fig. 6, February 2009, March 2010 and March 2011). At the end of the winter and summer the highest slope values are found in Zones 2, 3 , 4 and 5. Where a high dune exists (e.g. zone 2, 3, 4 and 5), the persistence of the berm is controlled by the maximum water reached by wave run-up during storms, in protecting the dune toe and has no direct control on backshore evolution.

The dune front has a more complex evolution (Fig. 6). The steepening of the dune front generated by the erosive effect of storm waves at the toe of the dune is referred to here as the "standard" response of the dune face,, comparable to the Cliffed Stoss slope-CS morphology of Ollerhead et al. (2013). High slope values can be reached because plant roots keep the sand together. The presence of plant debris gives the dune further resistance. If the storm erosion in winter is significant but does not cause deep scour, the plants can prevent the collapsing of the dune crest and the retreat of the mound. In the summer, roots are exposed to salt water and winds, so the plants die and the sand of the dune dries out, causing collapse of the material from the crest to the dune foot. If enough time exists, the dune system can partially recover, in particular where the beach is wide enough to supply sediment to the mounds. This was observed however only in Zone 1 (Bevano mouth) where overwash occurs. In the rest of the study area the dominant process was dune cliffing. To schematize the standard slope evolution the following conceptual model is presented:

1. During the winter, the dune is eroded by the waves and consequently the slope of the frontal dune after storms is steep; 
2. During the summer, the frontal dune collapses and has a lower slope because of the sand accumulated at its toe;

3. Ideally, if the dunes remain untouched, the slope would continue to decrease and reach an equilibrium profile.

Some exceptions from the standard response need to be taken into account. In Zone 4 between February and March 2010 a decrease of the slope occurred. This mechanism is different from that observed generally across the whole study site, so it is referred to here as "discrepant" response. We assume that a $20 \%$ increase or decrease in slope values between two successive surveys is significant (considering the instrumental precision and capability to survey exactly the same points along the profile in every campaign). Ollerhead et al. (2013) describe a decrease in foredune slope after a storm through the action of waves impacting at the base of the dune face. According to these authors, this happens during moderate storms, whereas the stronger storms should produce a steep cliff. We provide (below) an alternative explanation for this mechanism, which we believe is controlled by occasional slumping of the dune crest.

As an example, Figure 9 indicates a discrepant response of the dune slope at profile MS22 after the very intense March 2010 storm (Fig. 2) in comparison with the standard response at profile MS17. A reduction of the slope for this storm was in fact observed while, after the previous events, the slope was always higher (Fig. 9a). Taking into account the survey done in February 2010, it is possible to see that the steepness of the dune front is higher than the one measured one month later (Fig. 9b).

This response is probably a result of the intense erosion during the storm of March 2010, causing collapse of the upper part of the dune and generating a milder dune slope and dune foot retreat (Fig. 9b). Some profiles follow the standard response (Fig. 9a), but most of the sections in Zone 4 follow the discrepant mechanism (Fig. 9b). The dune ridge, where the discrepant mechanism was 
observed, is low and narrow and, thus, not capable of resisting wave attack. The discrepant mechanism, portrayed in Fig. 9b, is probably generated by the sequence of storms in winter 2010 that eroded the dune. The March storm acted upon an already eroded dune system causing the collapse of the crest and the strong erosion of the first line of mounds. The formation of a sand apron at the dune toe, referred to as a "dune ramp" by Ollerhead et al. (2013), could provide feedback to dunes according to the previous authors. This implies that wind transport transfers the sediment back to the dune crest and that wave action does not completely remove the material during subsequent storms. In the case of the current paper the latter process is dominant over the former.

Figure 9 goes approximately here

Armaroli et al. (2012) found that the present study area was already significantly affected by storms occurring in winter 2008-2009. They state that the dune system was frontally eroded and overwashed. It could be argued that the dunes were already less "resilient" to storm action and that the storm of March 2010 found many sites at the onset of a critical situation.

Comparison with other "long-term" datasets of dune morphology (e.g. Ollerhead et al., 2013) is difficult, because the physical setting of the dunes is different from other open coast systems. The system studied here is essentially a regressive system in an erosional cycle (Hesp, 2002; Saye et al., 2005). Ciavola and Armaroli (2010) studied the coastal section north of the Bevano from 2001 to 2007 and observed a continuous degradation of the foredune, evolving from a scarped faced like that of Zones 3 and 4 into an isolated mound morphology as discussed by Short and Hesp (1982). In this model a clear sign of dune degradation is the development of isolated mounds in the foredunes, where vegetation is degraded by salt-spray. Blow-outs can develop in between these mounds, 
triggering an erosive phase which eventually leads to the obliteration of the dune ridge (Byrne, 1997; Jungerius and Van der Meulen, 1997; Fraser et al., 1998).

The process of inland sand transfer can be fully observed in the zone immediately to the south of the Bevano river mouth (Zone 1), where the elevation of the dune crest is low and a constant transfer of sediment occurs from the berm to the backshore during surges (see Fig. 5 and 7). Once sand is transferred from the berm to the upper beach, this can be colonized by plants which are present at the site, like Cakile maritima, Agropyron junceum and Ammophila littoralis, and the system becomes progressively more stable. In this case a direct relationship between berm presence and stability and foredune development can be considered, as proposed by McLean and Shen (2006) when examining a multi-decade dataset from Australia.

\subsection{Beach morphodynamic classification}

Comparing the two classifications, both give a similar result, stating that the beach, from the Bevano mouth southwards to the protected area of Lido di Classe, decreases its slope and becomes more dissipative. The Short (1999) classification, however, does not exactly correspond to the Masselink and Short (1993) for Zone 5. The Masselink and Short (1993) classification suggests that the area is dissipative, while the Short (1999) model suggests that the beach is intermediate. This difference probably results from the presence of groins and the submerged shore-parallel breakwater that causes the sedimentation of finer sands. Moreover, the $\Omega$ value is 5.07 and, thus, at the boundary between intermediate and dissipative beach according to Masselink and Short (1993).

Zone 5 represents the southern boundary of the natural area and is protected by three groins and a submerged breakwater (geotextile sand bags). The area was classified according to Masselink and Short (1993) and Short (1999) because, even if it is protected by artificial structures, it has bars, 
berm and sand dunes, that are equivalent to those located in the fully natural zone northwards. We suppose that the groins do not deeply affect longshore transport, because they do not have the characteristic erosion or accumulation zones. The presence of the dunes and the natural response justifies the definition of Zone 5 as a "semi-natural area". Zone 6, on the contrary, is fully protected and influenced by human structures located in front and on the beach.

\subsection{Foredune erosion during storms}

Results of XBeach modelling show that the model is able to predict the erosion of the duneface with relative accuracy when certain parameter adjustments are made. The parameters related to dune slumping - the critical slope before avalanching commences in the model - appear to be important in modelling dune erosion at this site. The role between avalanching and dune erosion has been described by Roelvink and Renier (2012) by comparing XBeach results and flume data. It appears that without avalanching, dune erosion is severely under predicted. According to the authors, the avalanching mechanism is triggered by swash processes in the infragravity band, thus both processes must be present in a numerical model to explain the mechanisms of dune erosion. This poses limits to simpler numerical models that do not account for the longer part of the energy spectrum. In the numerical tests presented in the current paper, improved model performance is observed when the value of the critical avalanching slope for wet sand ('wetslp') is increased from its default value of 0.3 to 0.5 . As a comparison, the dry slope critical value, suggested by Roelvink and Reniers (2012), is 1. This suggests that higher critical slopes are attainable than that under default model settings. A possible explanation for this is the role of vegetation in stabilising the dune, which is currently unaccounted for in XBeach. To achieve more realistic simulations of dune slumping (including the role of dune vegetation), a more processed-based model of dune slumping processes may be required (Palmsten and Holman, 2011). A possible approach could be to introduce in the code geotechnical parameters describing the resistive strength of the dune, like 
done by Erikson et al. (2007). These authors provide a detailed physical explanation of the types of dune failure, with their module of "mass failure with shearing" being the closest to our field observations. Their model is only based, however, on flume experiments, where the biotic component was not present.

\subsection{Dune impact indicators}

The comparison between the observed impact of 2008-2009 storms on the dune system and the impact scale of Sallenger (2000) and the DSF of Armaroli et al. (2012) shows a very good correspondence, supporting the use of the centroid of the dune volume as used by Judge et al. (2003) The DSF parameter of Armaroli et al. (2012) introduces an additional index for dune stability, but its reliability should be proved on dune systems with much larger sediment volumes and on areas exposed to much higher forcing under extreme storm conditions (e.g. hurricane force on oceanic beaches).

\section{Conclusions}

Response of beach-dune to severe storms in the study area was investigated using topographic surveys (7 over an approximately 3-year period), bathymetric surveys and sediment samples.

The beach (backshore and swash zone) did not show any seasonal trend whereas the dune system showed two different responses. The main outcome was the identification of a frontal dune response that did not follow the standard dune evolution in the area and that, for this reason, was called "discrepant". This mechanism took place when the frontal dune slope decreased between two surveys performed before and after a storm. The "standard response" corresponded to an increase of the dune front slope after a storm. The occurrence of the "discrepant" mechanism was explained by 
the scour generated by waves during storms and high water level, producing a collapse of the upper part of the dune. This process accumulated sand at the dune toe, thus, decreasing the dune front slope. It was found that this discrepant dune response was also related to a narrow backshore. The analysis of the dune front slope evolution between the winter and the summer, and vice-versa, revealed that the discrepant response was symptomatic of an eroding stretch of coast, where the dune system is severely affected by storms and not able to recover during conditions of calm weather.. On this coastline, onshore wind transport potential is limited as well as sediment export from the rear dune to the foredune, because of a pine forest behind the dunes. Thus, dunes do not recover after extreme erosion, except in the area close to the Bevano River where sand is abundant and able to favour embryo dune formation

Two storm impact indicators were tested, one based on the maximum water level elevation during storms (Sallenger, 2000) and one based on the volume of sediment above that level (Armaroli et al., 2012). A state-of-the-art profile numerical model was run to test its capability in predicting the evolution of beach profiles and dune erosion during energetic events. The three methods provided good agreement in estimating the storm impacts, proving that even simple indicators can be used for predictive purposes.

No direct relationship between beach morphodynamics and dune erosion was found. The studied beaches showed reasonably homogeneous morphodynamic response using the most widely used classification. Anomalous responses were identified where river influence, overwash processes or human disturbances were present. This indicates that limits in the current morphodynamic classifications exist, for example for areas where occasional flooding takes place. Where river flooding had occurred, e.g. near the river mouth, the beach profile was flat. Likewise overwashing flattened the lower beachface with berm accretion at the edge of maximum run-up level. Traditional 
morphodynamic classifications seem inappropriate for beaches behind structures where, in addition to disturbance effects by the coastal defences, beach scraping or summer artificial beach flattening produce unnatural slopes (Harley and Ciavola, 2013).

The prediction of dune erosion and vulnerability to storms can be used to assess resilience of coastal areas where these barriers provide the first line of defence for decreasing storm impact. This paper showed correspondence between process-based modelling and empirical estimations of storm impacts. Both approaches are suggested for the evaluation of potential hinterland flooding. The use of one method rather than the other is controlled by the availability of detailed digital terrain models (e.g. Lidar based) and the capability of running at least 1-d profile models.

Field observations have confirmed the importance of biotic factors, e.g. presence of plant roots, in generating steep frontal dune slopes, that are not easily explained using simple geotechnical laws (e.g. repose angle of material). This poses a limit for most numerical modelling techniques. We suggest running laboratory tests aimed at providing a parameterization for this process.

\section{Acknowledgements}

The data used for the present paper was made available by the Project MICORE (Morphological Impact and COastal Risks induced by Extreme storm events) partially financed by the Commission of the European Communities within Framework VII, Environment and Climate Change theme (contract 202798). Further details for the project are available on www.micore.eu. We thank Mouncef Sedrati for assistance in obtaining field data. 


\section{References}

Armaroli, C., Balouin, Y., Ciavola, P., Capatti, D., 2005. Nearshore bars as a natural protection of beaches, field evidence from Lido di Dante beach, Adriatic sea. Proceedings of ICCM'05 Conference, Tavira, Algarve, Portugal, EUROCOAST Portugal, pp. 295-303.

Armaroli, C., Ciavola, P., 2011. Dynamics of a nearshore bar system in the northern Adriatic: a video-based morphological classification. Geomorphology 126, 201-216.

Armaroli, C., Ciavola, P., Caleffi, S., Gardelli, M., 2007a. Morphodynamics of nearshore rhythmic forms: an energy-based classification. Proceedings of 30th International Conference on Coastal Engineering, ASCE, pp. 4009-4021.

Armaroli, C., Ciavola, P., Perini, L., Luciani, P., 2007b. Morfologia delle spiagge ravennati e vulnerabilità per fenomeni di inondazione. In: Terzo Forum Nazionale, Pianificazione e tutela del territorio costiero; questioni, metodi, esperienze a confronto, Maggioli Editore, Santarcangelo di Romagna (RN), vol. 127, pp. 363-389. (in Italian).

Armaroli, C., Ciavola, P., Perini L., Lorito, S., Valentini, A., Masina, M., 2012. Critical storm thresholds for significant morphological changes and damage along the Emilia-Romagna coastline, Italy. Geomorphology 143-144, 34-51.

Balouin, Y., Ciavola, P., Armaroli, C., 2006. Sediment transport pattern and coastal evolution at Lido di Dante beach Adriatic sea. Proceedings of Coastal Dynamics 2005, Barcelona, ASCE.

Blott S.J., Pye K., 2001. Gradistat: a grain size distribution and statistics package for the analysis of unconcolidated sediments. Earth Surf. Proc. and Land. 26, 1237-1248

Byrne, M.L., 1997. Seasonal sand transport through a trough blowout at Pinery Provincial Park, Ontario. Can. J. Earth Sci. 34, 1460-1466. 
Calabrese, L., Lorito, S., 2009. Geomorfologia costiera In Il sistema mare-costa dell'EmiliaRomagna. Perini L. and Calabrese L. (eds), Pendragon, Bologna, cap. 7, pp. 87-108. (in Italian).

Ciavola, P., Armaroli, C., 2010. Evoluzione recente del sistema dunale di Lido di Dante-Foce Bevano (Ravenna): fattori naturali ed impatto antropico. Studi Costieri 17, 19-38. (in Italian)

Dean, R.G., 1973. Heuristic models of sand transport in the surf zone. Proceedings of the Conference on Engineering Dynamics of the Coastal Zone, Sidney, N.S.W., Australia, pp. 208-214.

Doody, J.P., 1992. Nature conservation on the coast: the role of coastal zone management. In: Carter, R.G.W., Curtis, T.G.F. and Shelley-Skeffington, M.J., Coastal Dunes, Balkema, Rotterdam, pp. 495-502.

Edelman, T., 1968. Dune erosion during storm conditions. Proceedings of 11th Conference on Coastal Engineering, ASCE, pp. 719-722.

Erikson, L.H., Larson, M., Hanson, H., 2007. Laboratory investigation of beach scarp and dune recession due to notching and subsequent failure. Mar. Geol. 245, 1-19.

FEMA (Federal Emergency Management Agency), 2003. Guidelines and Specifications for Flood Hazard Mapping Partners. Appendix D: Guidance for Coastal Flooding Analyses and Mapping, April 2003.

Folk, R.L., Ward, W.C., 1957. Brazos River bar: a study in the significance of grain size parameters. Journal of Sed. Pet. 27, 3-26.

Fraser, G.S., Bennett, S.W., Olyphant, G.A., Bauch, N.J., Ferguson, V., Gellasch, C.A., Millard, C.L., Mueller, B., O’Malley, P.J., Way, J.N., Woodfield, M.C., 1998. Windflow circulation patterns in a coastal dune blowout, south coast of Lake Michigan. J. Coastal Res. 14, 451-460. 
Grottoli, E., Ciavola, 2012. Morfodinamica e risposta a corto e medio termine ad eventi di mareggiata delle spiagge comprese tra Foce Bevano e Lido di Classe (RA). Studi Costieri. (in Italian).

Harley, M., Armaroli, C., Ciavola, P., 2011. Evaluation of XBeach predictions for a real-time warning system in Emilia-Romagna, Northern Italy. J. Coastal Res. SI 64, 1861-1865.

Harley, M., Ciavola, P., 2013. Managing local coastal inundation risk using real-time forecasts and artificial dune placements. Coastal Eng. 77, 77-90.

Hesp, P., 2002. Foredunes and blowouts: initiation, geomorphology, and dynamics. Geomorphology 48, 245-268.

Holman, R.A., 1986. Extreme value statistics for wave run-up on a natural beach. Coastal Eng. 9, 477-491.

Hughes, S.A., 1981. Beach and dune erosion during severe storms. Ph.D. thesis. University of Florida.

Idroser, 1996. Progetto di Piano per la difesa del mare e la riqualificazione ambientale del litorale della Regione Emilia-Romagna. Regione Emilia-Romagna, Bologna, Italy, 365p. (in Italian)

Judge, E.K., Overton, M.F., Fisher, J.S., 2003. Vulnerability indicators for coastal dunes. J. Waterw. Port C. 129, 270-278.

Jungerius, P. D., Van der Meulen, F., 1997. Aeolian dynamics in a blowout complex in the Meijendel dunes, The Netherlands. Journal of Coastal Conservation 3, 63-70.

Kriebel, D.L., Dean, R.G. 1993. Convolution method for time-dependent beach-profile response. J. Waterw. Port C. 119, 204-226.

Larson, M., Kraus, N.C., 1989. SBEACH: Numerical Model for Simulating Storm-Induced Beach Change. CERC-89-9, US Army Corps of Engineers, Vicksburg. 
Le Roux, J.P., 1996. An EXCEL program for computing the dynamic properties of particles in Newtonian fluids. Computers and Geosciences 23, 671-675.

Lindemer, C.A., Plant, N.G., Puleo, J.A., Thompson, D.M., Wamsley, T.V., 2010. Numerical simulations of a low-lying barrier island's morphological response to Hurricane Katrina. Coastal Eng. 57, 985-995.

Masina, M., Ciavola, P., 2011. Analisi dei livelli marini estremi e delle acque alte lungo il litorale ravennate. Studi Costieri 18, 84-98. (in Italian)

Masselink, G., Short, A.D., 1993. The effect of tide range on beach morphodynamics. J. Coastal Res. 9, 785-800.

Masselink, G., Hegge, B., 1995. Morphodynamics of meso-macrotidal beaches: examples from central Queensland, Australia. Mar. Geol. 129, 1-23.

McCall, R., Van Thiel de Vries, J., Plant, N., Van Dongeren, A., Roelvink, J., Thompson, D., Reniers, A., 2010. Two-dimensional time dependent hurricane overwash and erosion modeling at Santa Rosa Island, Coastal Eng. 57, 668-683.

McLean, R., Shen, J.S., 2006. From foreshore to foredune: foredune development in the last 30 years at Moruya Beach, New South Wales, Australia. J. Coastal Res. 22, 28-36.

Nordstrom, K.F., Gamper, U., Fontolan, G., Bezzi, A., Jackson, N., 2009. Characteristics of coastal dune topography and vegetation in environments recently modified using beach fill and vegetation plantings, Veneto, Italy. Env. Management 44, 1121-1135.

Ollerhead, J., Davidson-Arnott, R., Walker, I. J., Mathew, S., 2013. Annual to decadal morphodynamics of the foredune system at Greenwich Dunes, Prince Edward Island, Canada. Earth Surf. Proc. and Land. 38, 284-298. doi: 10.1002/esp.3327 
Overton, M.F., Pratikto, W.A., Lu, J.C., Fisher, J.S., 1994. Development of a dune erosion model using SUPERTANK data. Proceedings of 24th International Conference on Coastal Engineering, ASCE, Kobe, Japan.

Palmsten, M.L., Holman, R.A., 2011. Infiltration and instability in dune erosion, J. Geophys. Res., 116 (C10030), 1-18.

Raubenheimer, B., Guza, R.T., 1996. Observations and predictions of run-up, J. Geophys. Res., 101 (C10), 25575-25587.

Roelvink, J.A, Reniers, A., van Dongeren, A., van Thiel de Vries, J., McCall, R., Lescinski, J., 2009. Modeling storm impacts on beaches, dunes and barrier islands. Coastal Eng. 56, 11331152.

Roelvink, J.A, Reniers, A., 2012. A guide to modeling coastal morphology. Advances in Coastal and Ocean Engineering, vol. 12, World Scientific, Singapore, 274 pp.

Sallenger, A.H., 2000. Storm impact scale for barrier islands. J. Coastal Res. 16, 890-895.

Saye, S.E., van der Wal, D., Pye, K. Blott, S.J., 2005. Beach-dune morphological relationships and erosion/accretion: an investigation at five sites in England and Wales using LIDAR data, Geomorphology 72, 128-155.

Sedrati, M., Ciavola, P., Armaroli, C., 2011. Morphodynamic evolution of a microtidal barrier, the role of overwash: Bevano, Northern Adriatic Sea. J. Coastal Res. SI 64, p. 696-700

Sedrati, M., Ciavola P., Reyns J., 2008. Swash bar behaviour on a protected microtidal beach: Lido di Dante, Italy. In: Proceedings 3rd International Short Conference/Course on Applied Coastal Research. Lecce, Nuova Editoriale Bios, pp. 153-164

Sedrati, M., Ciavola P., Reyns, J., Armaroli, C., Sipka, V., 2009. Morphodynamics of a microtidal protected beach during low wave-energy conditions. J. Coastal Res. SI 56, 198-202. 
Short, A.D., Hesp, P.A., 1982. Wave, beach and dune interactions in southeastern Australia. Mar. Geol. 48, 259-284.

Short, A.D., 1999. Handbook of Beach and Shoreface Morphodynamics. Wiley, Chichester, 392pp.

Splinter, K.D., Palmsten, M.L., 2012. Modeling dune response to an East Coast Low, Mar. Geol., Volumes 329-331, pp. 46-57.

Steetzel, H.J., 1993. Cross-shore Transport during Storm Surges. Ph.D. thesis. Delft University of Technology.

Van Thiel de Vries, J.S.M., 2010. Dune erosion during storm surges. PhD Thesis, Delft University of Technology, Delft, The Netherlands.

Vellinga, P., 1982. Beach and dune erosion during storm surge. Coastal Eng. 6, 361-387.

Vellinga, P., 1986. Beach and dune erosion during storm surges. Ph.D. Thesis, Delft University of Technology; also: WL| Delft Hydraulics report no. 372, December 1986.

Vousdoukas, M., Ferreira, O., Almeida, L., Pacheco, A., 2012. Toward reliable storm-hazard forecasts: Xbeach calibration and its potential application in an operational early-warning system, Ocean Dynam. 62, 1001-1015. 


\section{List of figures}

Figure 1 - Study area: location of the area on the topographic map of the Emilia-Romagna Region (upper right panel) and corresponding aerial photograph (2009 flight, EU Micore Project). The subdivision of the coast into six cells is indicated as well as the location of the profiles that were surveyed regularly. In the lower right panel the coastal protections in Lido di Classe are outlined.

Figure 2 -Significant wave height, mean wave period and water level during the study period. The field surveys, indicated by triangles at the top of the first graph, were done immediately after major events. The strongest storm occurred at the beginning of March 2010. The threshold of $\mathrm{H}_{\mathrm{s}}=1.5 \mathrm{~m}$ used to identify a storm, following the methodology of Armaroli et el. (2012), is indicated in the top panel.

Figure 3- Subdivision of the profiles into three segments (black bold lines in figure A and B). In figure A and B the locations of the sand samples (usually 5) taken along each section are indicated by squared arrows. Note that, if a bar was present, the number of samples becomes 6 to include that morphology in the sediment analysis.

Figure 4 - Characteristics of the two storms used for modelling storm impacts on the foredunes: significant wave height (Hsig), peak period (Tpeak), direction (Dir) and water level.

Figure 5-Six representative topo-bathymetric profiles of each zone of the study area. The elevation (y axes) is above/below MSL. The September 2009 bathymetry is also presented in the figure (dashed line indicates the portion of the profile with no data, because the topographic and bathymetric surveys were not connected) 
Figure 6 - Temporal variability of beach (backshore), swash zone slopes (upper panel) and dune front slope (lower panel): mean slope of each zone, for every survey. In the lower panel, frontal dune slope variability, zone 6 was removed because the dunes are in that area among buildings, thus, influenced by human activities.

Figura 7 - Morphodynamic classification of the study area. The labels in red indicate the classification of Masselink and Short (1993); the labels in white indicate the classification of Short (1999). Aerial photograph of March 2009.

Figure 8 - Comparison of modelled (XBeach code) beach and dune profile changes in response to storms with high water levels induced by surges (December 2008) and high waves (March 2010). The horizontal coordinate is relative to origin of the model.

Figure 9 - example of two profiles, located in Zones 3 (MS17) and 4 (MS22), that follow the standard (a) and the discrepant (b) mechanisms after the March 2010 storm. Note the erosion and recession of the dune after the storm in the "discrepant" profile.

\section{List of tables}

Table 1 - Statistics of profile configurations and measured storm response for the modelled two profile locations. Shoreline retreat is defined by the change in the $0.5 \mathrm{~m}$ contour line and the intertidal slope between the $\pm 0.3 \mathrm{~m}$ contours

Table 2 - Brier Skill Score results for XBeach model runs for the two storms using various combinations of parameter settings. Values in brackets indicate the BSS above MSL. Bold values indicate the optimum settings selected. 


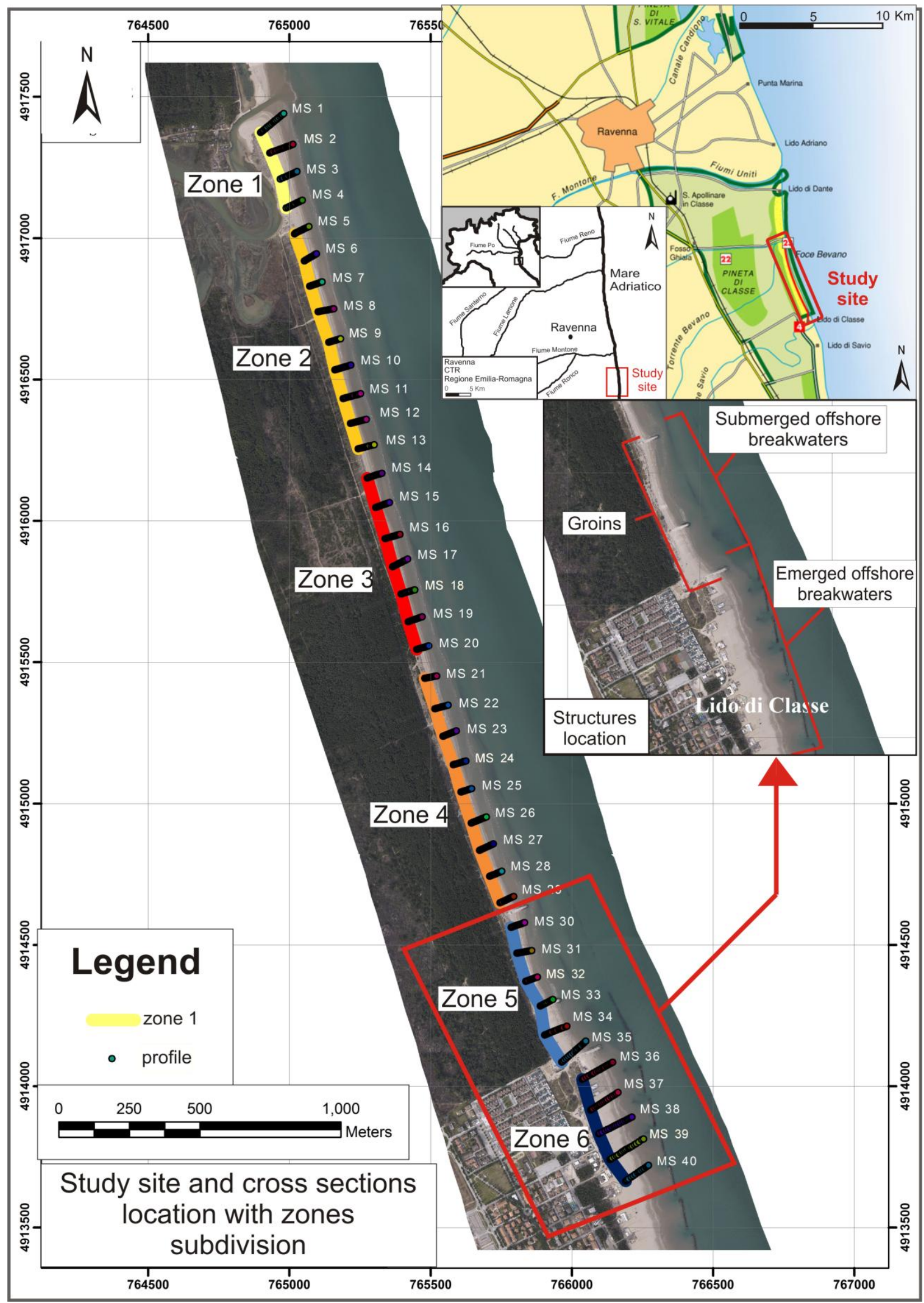

Fig. 1 

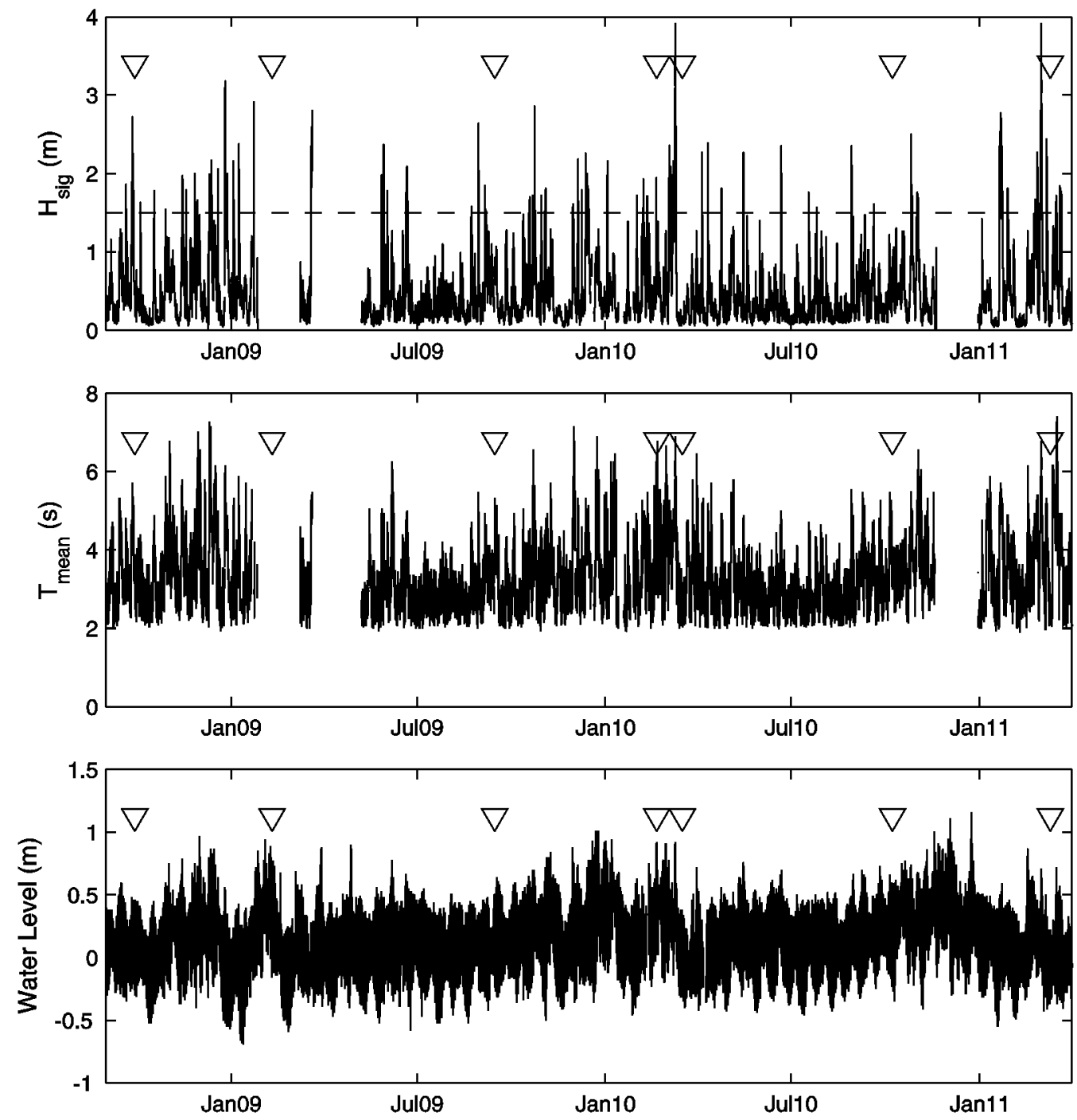

Fig. 2 
A)

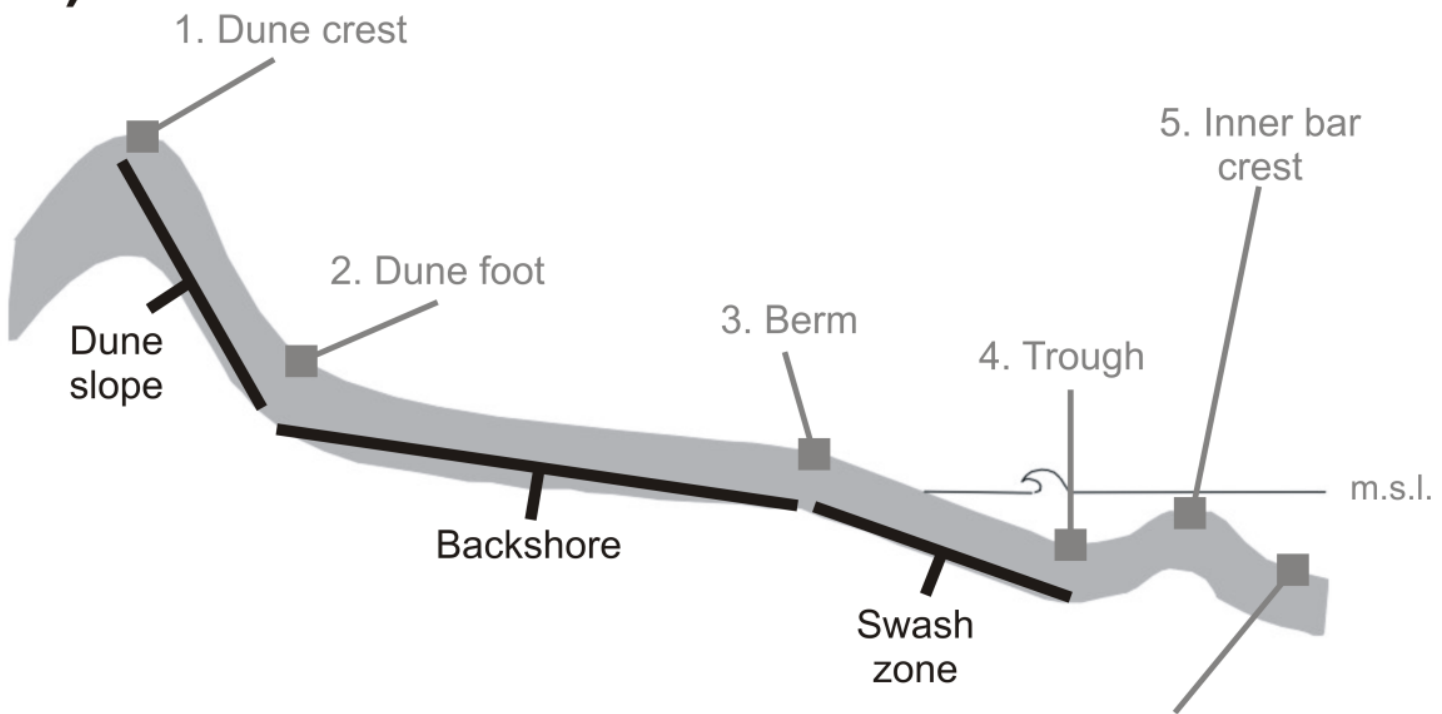

B)

6. Inner bar

base

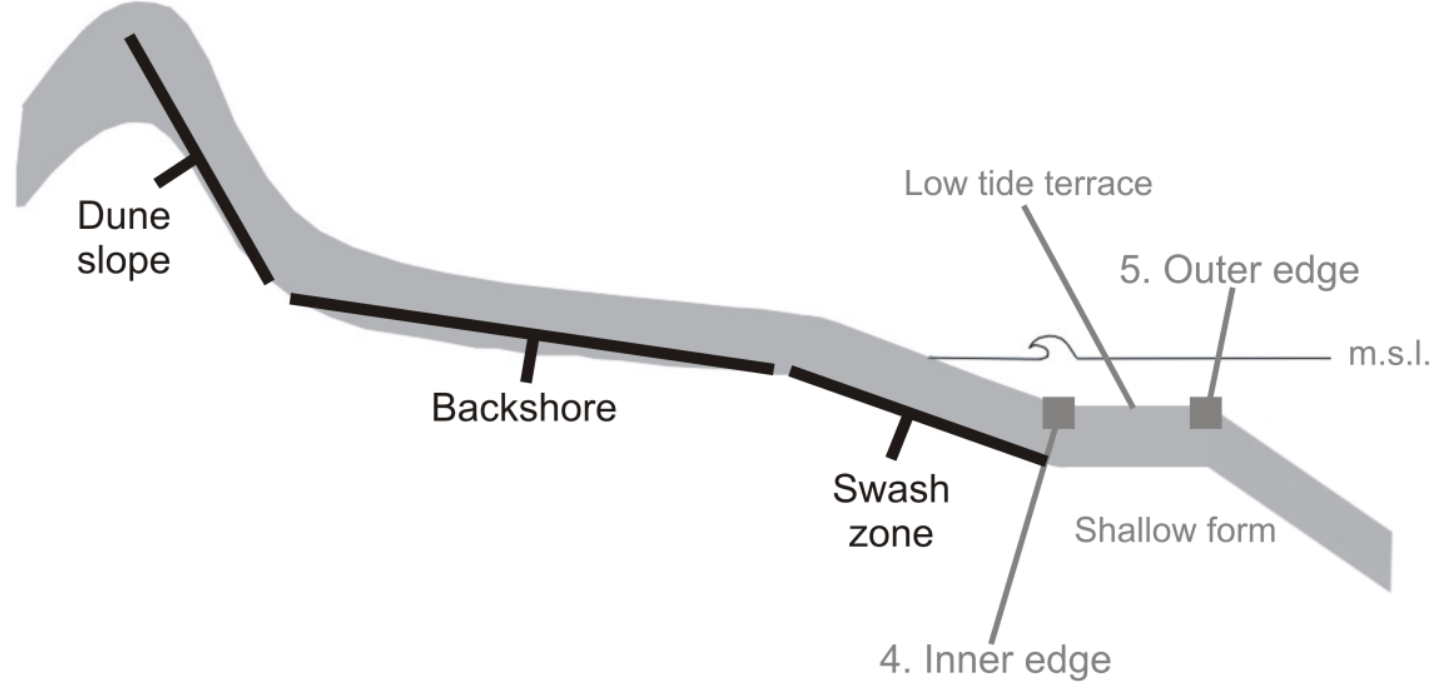

Fig. 3 

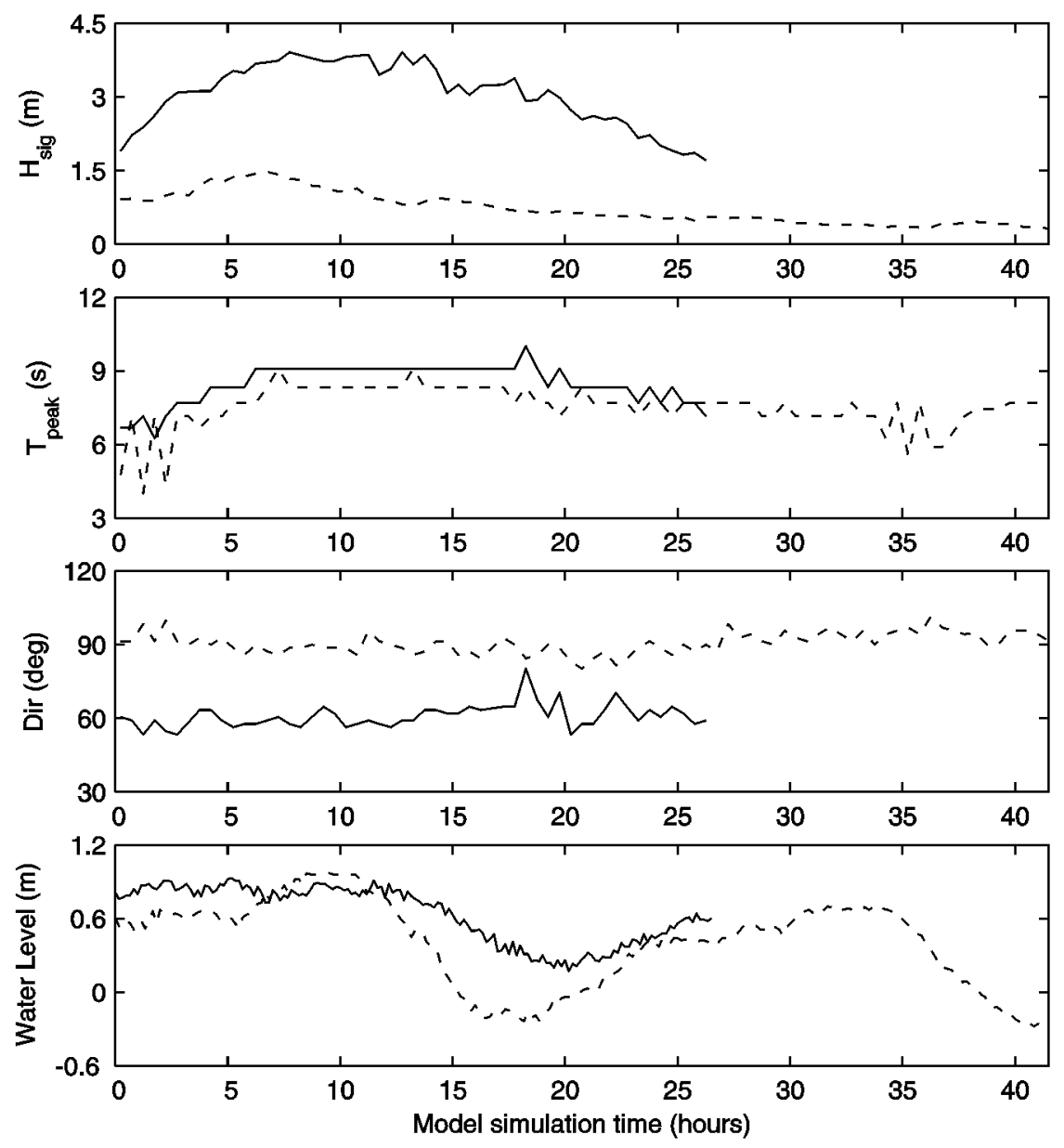

- - - - 1-3 Dec $2008 \longrightarrow$ 9-10 Mar 2010

Fig. 4 

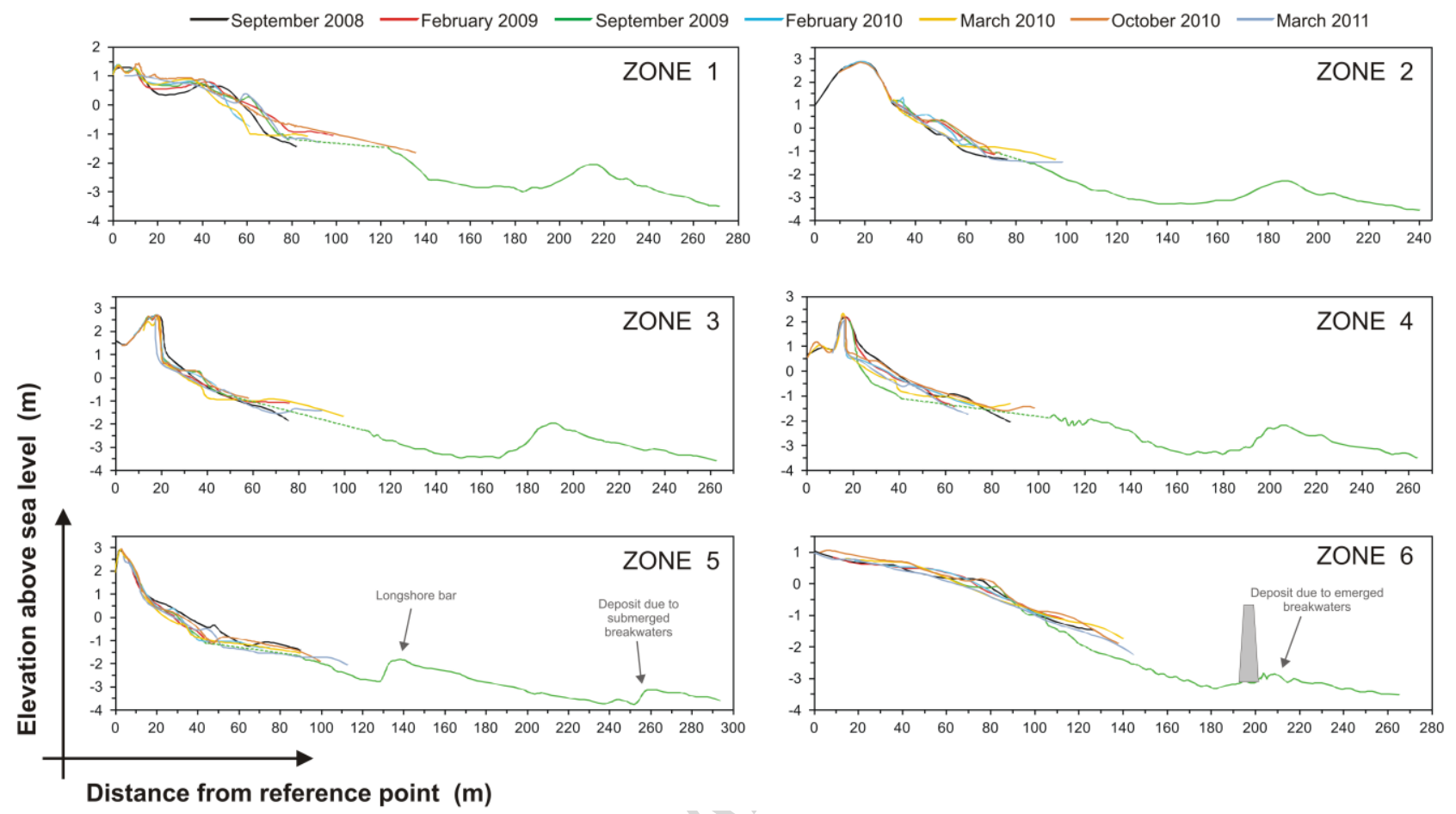

Fig. 5 

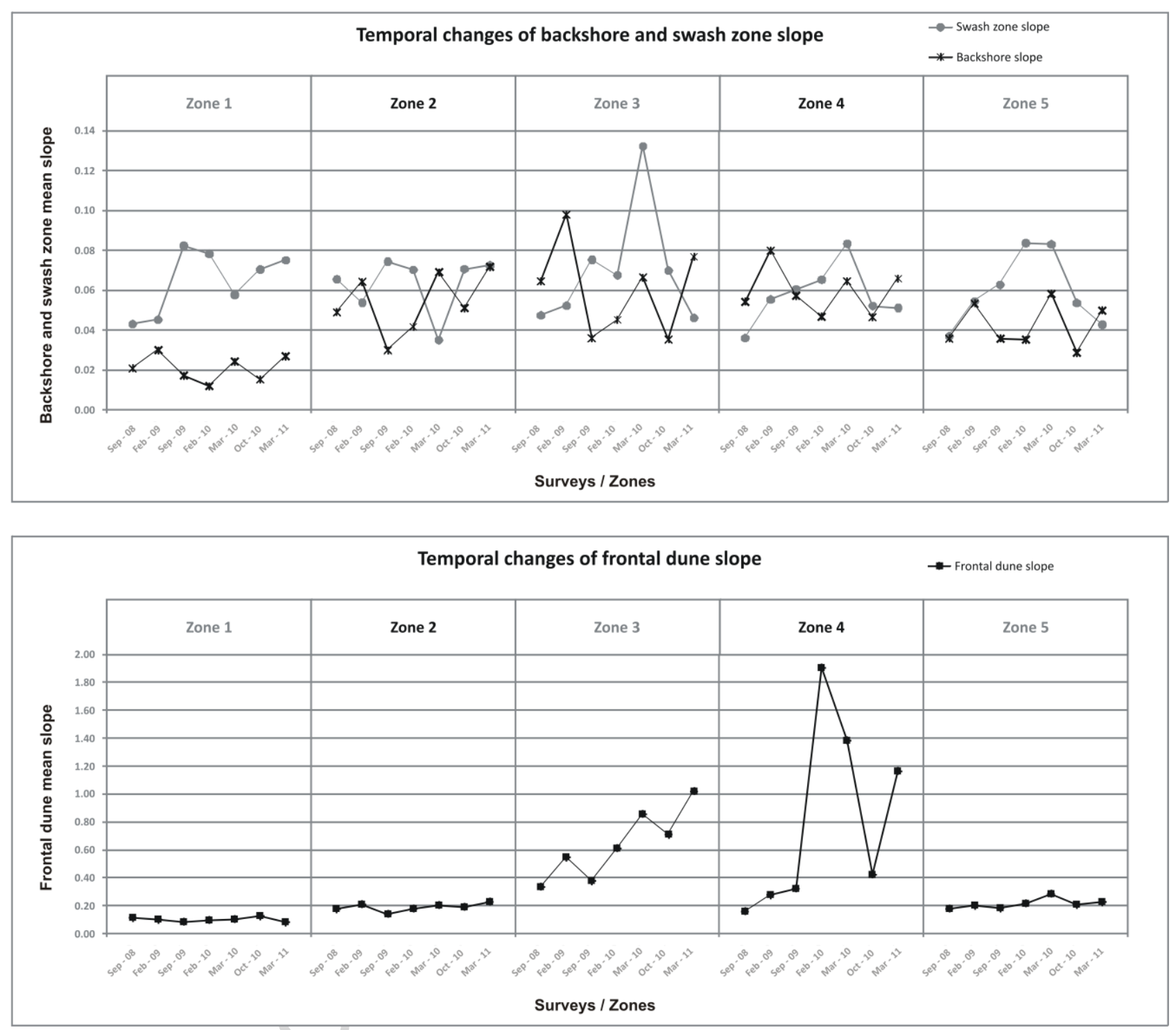

Fig. 6 


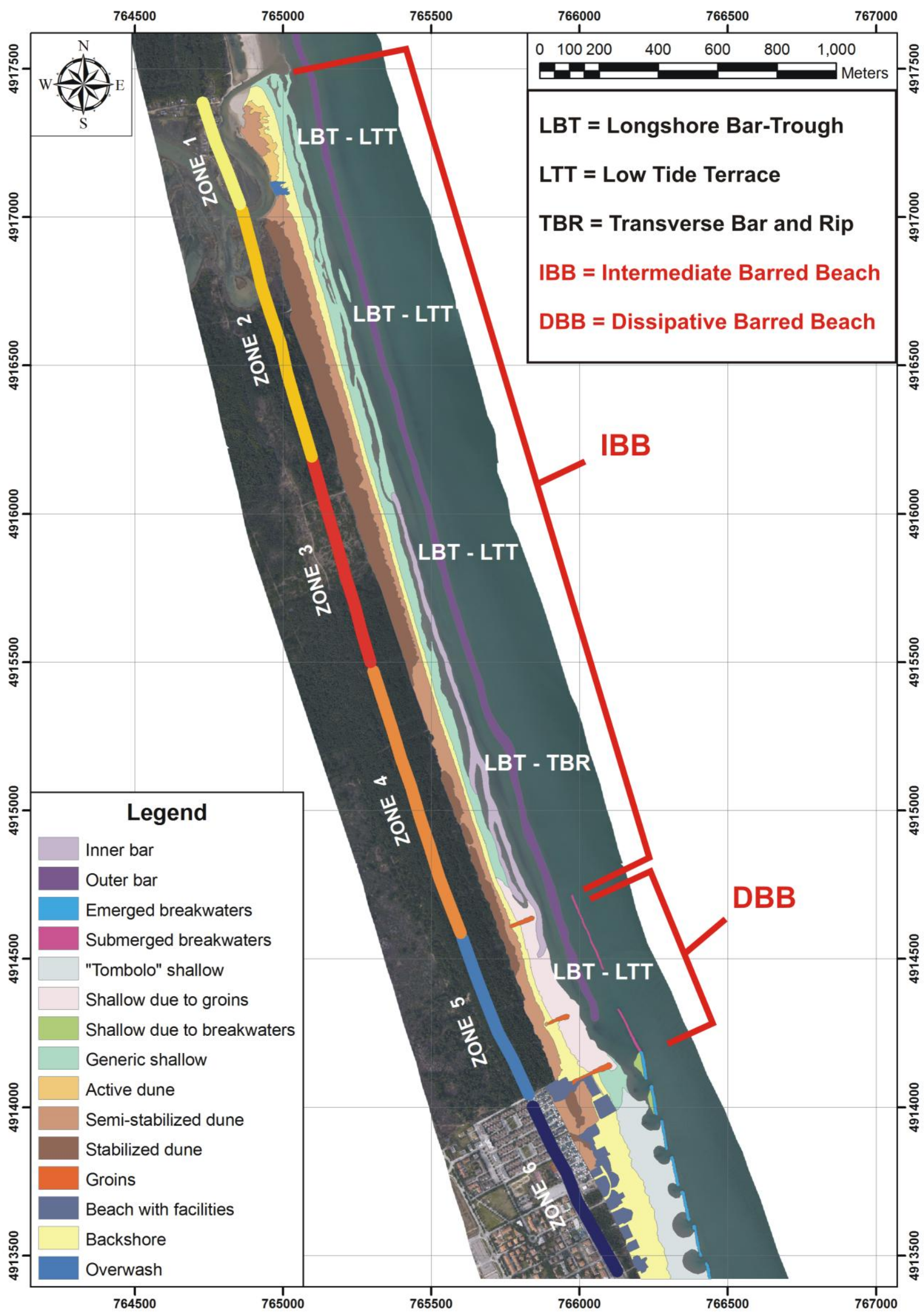

Fig. 7 

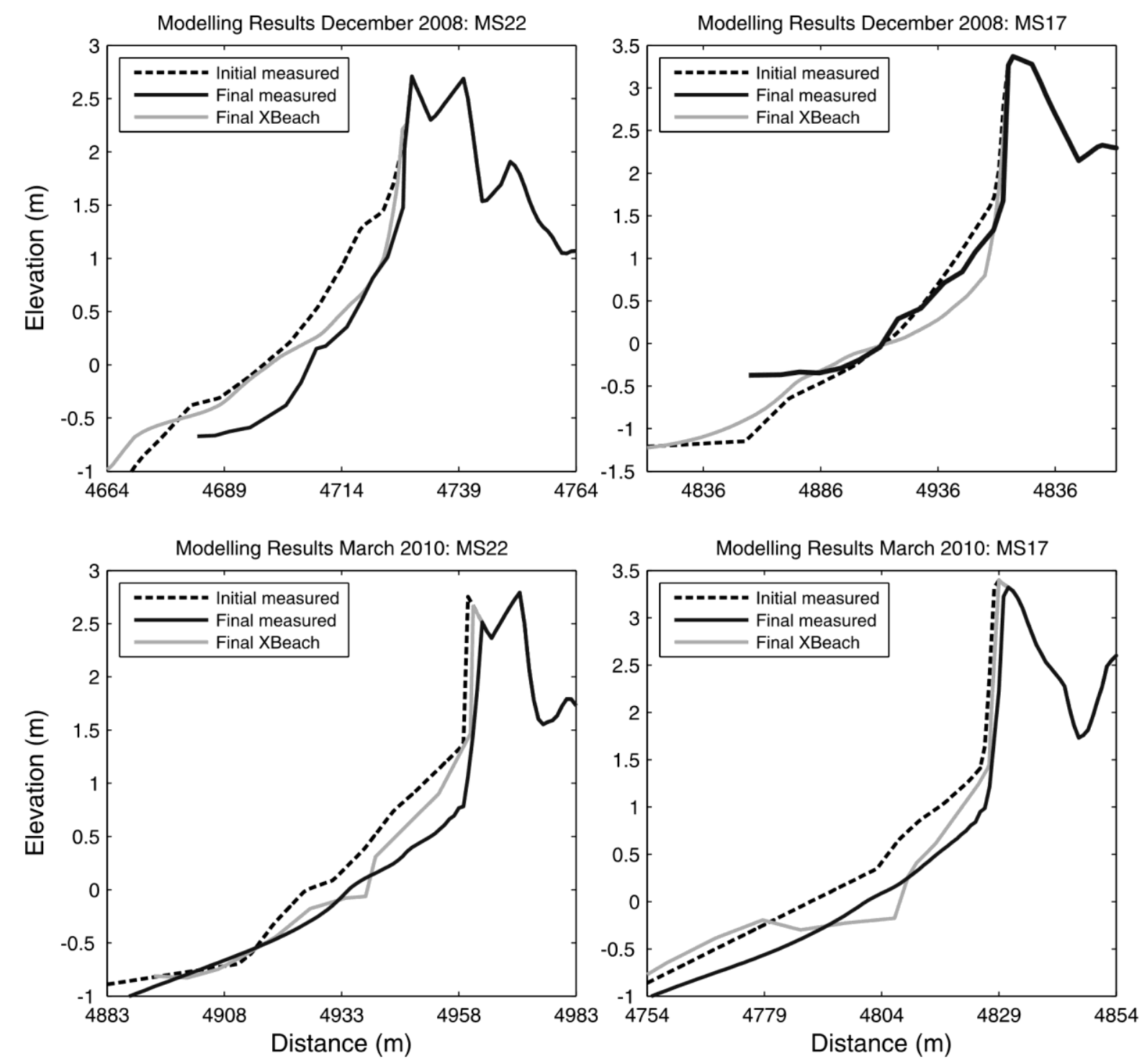

Fig. 8 
(a) Standard Response

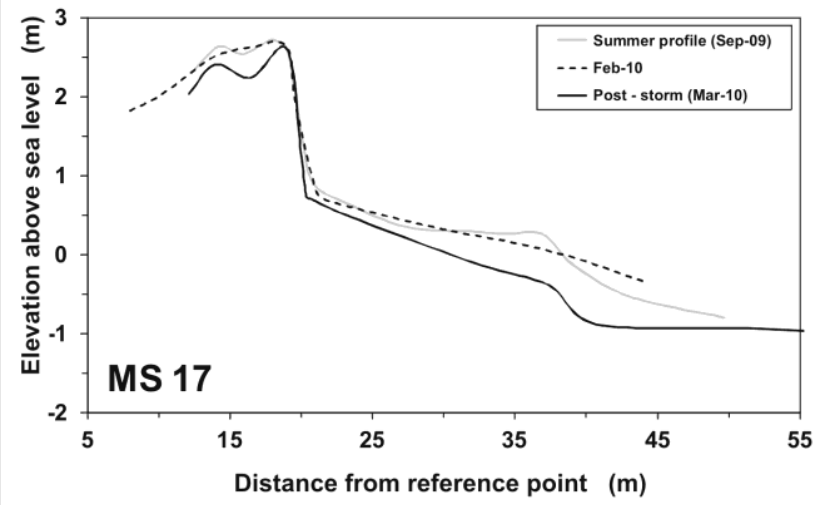

(b) Discrepant Response

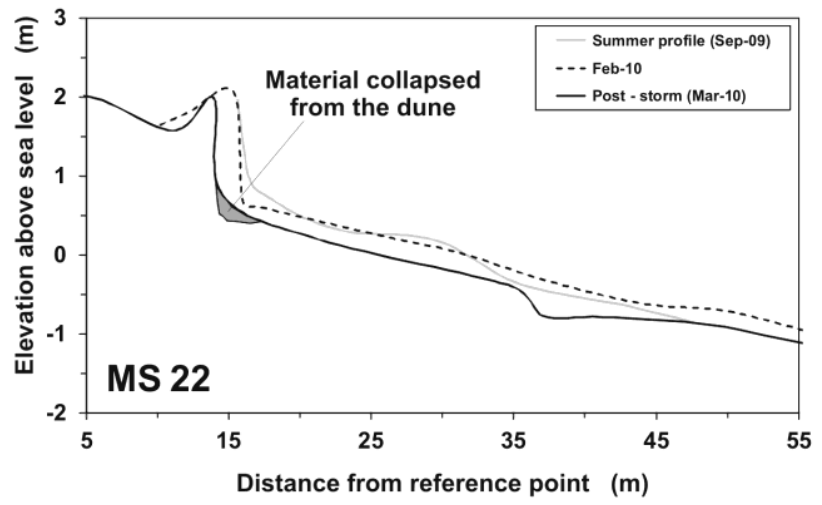

Fig. 9 
Table 1 - Statistics of profile configurations and measured storm response for the modelled two profile locations. Shoreline retreat is defined by the change in the $0.5 \mathrm{~m}$ contour line and the intertidal slope between the $\pm 0.3 \mathrm{~m}$ contours

\begin{tabular}{|l|cc|cc|}
\hline \multirow{2}{*}{ Profile } & \multicolumn{2}{|c|}{ December 2008 Storm } & \multicolumn{2}{c|}{ March 2010 Storm } \\
Statistic & MS22 & MS17 & MS22 & MS17 \\
\hline Dune crest height $(\mathbf{m})$ & 2.7 & 3.4 & 2.8 & 3.4 \\
Initial intertidal beach slope & $4 \%$ & $4 \%$ & $3 \%$ & $2 \%$ \\
Final intertidal beach slope & $6 \%$ & $4 \%$ & $2 \%$ & $1 \%$ \\
Shoreline retreat $(\mathbf{m})$ & 8.7 & 0.5 & 4.6 & 7.9 \\
Volume lost above MSL $\left(\mathbf{m}^{\mathbf{3}} / \mathbf{m}\right)$ & 13.2 & 4.0 & 8.3 & 12.6 \\
\hline
\end{tabular}


Table 2 - Brier Skill Score results for XBeach model runs for the two storms using various combinations of parameter settings. Values in brackets indicate the BSS above MSL. Bold values indicate the optimum settings selected.

\begin{tabular}{|c|c|c|c|c|c|}
\hline \multirow[b]{2}{*}{ Parameter set } & \multirow{2}{*}{$\begin{array}{l}\text { Storm } \\
\text { Alteration }\end{array}$} & \multicolumn{2}{|c|}{ December 2008} & \multicolumn{2}{|c|}{ March 2010} \\
\hline & & MS22 & MS17 & MS22 & MS17 \\
\hline \multirow{7}{*}{ Default } & None & $\begin{array}{l}0.56 \\
(0.73)\end{array}$ & $\begin{array}{l}-0.06 \\
(-1.16)\end{array}$ & $\begin{array}{l}-4.20 \\
(-4.47)\end{array}$ & $\begin{array}{l}-3.63 \\
(-3.87)\end{array}$ \\
\hline & dryslp $=0.5$ & $\begin{array}{l}0.51 \\
(0.80)\end{array}$ & $\begin{array}{l}0.02 \\
(-0.93)\end{array}$ & $\begin{array}{l}-20.67 \\
(-21.56)^{*}\end{array}$ & $\begin{array}{l}-2.84 \\
(-3.09)\end{array}$ \\
\hline & dryslp $=2$ & $\begin{array}{l}0.43 \\
(0.59)\end{array}$ & $\begin{array}{l}0.19 \\
(-0.60)\end{array}$ & $\begin{array}{l}-3.96 \\
(-3.95)\end{array}$ & $\begin{array}{l}-2.52 \\
(-2.55)\end{array}$ \\
\hline & wetslp $=0.1$ & $\begin{array}{l}-0.86 \\
(-0.86)\end{array}$ & $\begin{array}{l}-2.55 \\
(-6.90)\end{array}$ & $\begin{array}{l}-21.13 \\
(-22.58) *\end{array}$ & $\begin{array}{l}-9.12 \\
(-9.76)\end{array}$ \\
\hline & wetslp $=0.5$ & $\begin{array}{l}0.53 \\
(0.72)\end{array}$ & $\begin{array}{l}0.16 \\
(-0.62)\end{array}$ & $\begin{array}{l}0.45 \\
(0.44)\end{array}$ & $\begin{array}{l}0.07 \\
(0.28)\end{array}$ \\
\hline & gammax $=0.5$ & $\begin{array}{l}0.37 \\
(0.40)\end{array}$ & $\begin{array}{l}-0.41 \\
(0.03)\end{array}$ & $\begin{array}{l}-1.42 \\
(-1.47)\end{array}$ & $\begin{array}{l}-2.32 \\
(-2.46)\end{array}$ \\
\hline & gammax = 5 & $\begin{array}{l}-1.49 \\
(-1.28)\end{array}$ & $\begin{array}{l}-4.29 \\
(-10.77)\end{array}$ & $\begin{array}{l}-18.72 \\
(-19.50)^{*}\end{array}$ & $\begin{array}{l}-17.64 \\
(-18.73)^{*}\end{array}$ \\
\hline \multirow{7}{*}{ Parameter Set 1} & None & $\begin{array}{l}0.58 \\
(0.81)\end{array}$ & $\begin{array}{l}0.29 \\
(-0.16)\end{array}$ & $\begin{array}{l}-3.30 \\
(-3.38)\end{array}$ & $\begin{array}{l}-0.55 \\
(-0.40)\end{array}$ \\
\hline & dryslp $=0.5$ & $\begin{array}{l}0.60 \\
(0.78)\end{array}$ & $\begin{array}{l}0.23 \\
(-0.38)\end{array}$ & $\begin{array}{l}-2.72 \\
(-2.90)\end{array}$ & $\begin{array}{l}-0.33 \\
(-0.29)\end{array}$ \\
\hline & dryslp $=2$ & $\begin{array}{l}0.57 \\
(0.77)\end{array}$ & $\begin{array}{l}0.12 \\
(-0.74)\end{array}$ & $\begin{array}{l}-4.39 \\
(-4.59)\end{array}$ & $\begin{array}{l}-1.51 \\
(-1.38)\end{array}$ \\
\hline & wetslp $=0.1$ & $\begin{array}{l}-0.44 \\
(-0.39)\end{array}$ & $\begin{array}{l}-1.93 \\
(-5.85)\end{array}$ & $\begin{array}{l}-17.93 \\
(-18.48)^{*}\end{array}$ & $\begin{array}{l}-9.83 \\
(-10.49)\end{array}$ \\
\hline & wetslp $=0.5$ & $\begin{array}{l}0.60 \\
(0.70)\end{array}$ & $\begin{array}{l}0.16 \\
(-0.35)\end{array}$ & $\begin{array}{l}0.10 \\
(0.06)\end{array}$ & $\begin{array}{l}0.17 \\
(0.56)\end{array}$ \\
\hline & gammax $=0.5$ & $\begin{array}{l}0.25 \\
(0.20)\end{array}$ & $-0.44(0.00)$ & $\begin{array}{l}0.43 \\
(0.52)\end{array}$ & $-0.68(0.45)$ \\
\hline & gammax $=5$ & $\begin{array}{l}-1.49 \\
(-1.28)\end{array}$ & $\begin{array}{l}-4.29 \\
(-10.77)\end{array}$ & $\begin{array}{l}0.28 \\
(0.34)\end{array}$ & $\begin{array}{l}-15.95 \\
(-16.65)^{*}\end{array}$ \\
\hline
\end{tabular}




\section{Highlights}

- Storm beach behaviour was compared it with seasonal (months) and medium-term (3-year) morphodynamic change.

- The swash zone slope did not show any significant variability. A weak seasonal trend in the variability of the mean foredune slope was observed, with steeper slopes typically during winter and flatter slopes during summer.

- Storm events are considered the main factor controlling beach and dune slope changes. Contrary to the seasonal dune trend, several foredune slopes were observed to flatten following a significant storm, which can be attributed to the action of dune slumping from the already weakened dune state.

- Modelling of foredune erosion using a process-based model (XBeach) reproduced the erosion of the upper beach and dune toe reasonably well, but is currently limited by the acceptable slope value for dune stability, which does not account for biotic factors (e.g. plant roots). 